Article

\title{
Equitable and Reasonable Utilization: Reconstructing the Nile Basin Water Allocation Dialogue
}

\author{
Abby Muricho Onencan * (D) and Bartel Van de Walle \\ Policy Analysis Section, Multi-Actor Systems (MAS) Department, Faculty of Technology, Policy and \\ Management, Delft University of Technology, Building 31, Jaffalaan 5, 2628 BX Delft P.O. Box 5015, \\ 2600 GA Delft, The Netherlands; B.A.vandeWalle@tudelft.nl \\ * Correspondence: a.m.onencan@tudelft.nl; Tel.: +31-15-27-81-810
}

Received: 28 February 2018; Accepted: 25 May 2018; Published: 30 May 2018

check for updates

\begin{abstract}
Equitable and reasonable utilization is a core principle in the distribution of water resources. However, its practical application in the Nile Basin has been a significant challenge, leading to a water allocation deadlock. To address the deadlock, we used the van Eeten (1999) four-step process for defining new agendas. To reconstruct the debate, nine possible water allocation methods are developed using the Stone (2002) framework. After that, the arguments are compared and contrasted using interpretative policy analysis and the relevant factors to determine equitable and reasonable utilization in the Nile basin. Unfortunately, none of the nine possible water allocation methods satisfied all of the factors of assessing equitable and reasonable utilization. Therefore, we identified a crosswalk position that combines three water allocation methods. This combination consists of: (1) a group-based distribution; (2) a value-based distribution; and (3) a consensus-based distribution. Since the crosswalk position does not address current and potential uses, we recommend a new agenda to recast the issue. This agenda entails a change in the recipient of the water resources, the allocated item, and the process of decision-making. Finally, we discuss the potential of applying the proposed methodology in Nile sub-basins and other river basins within Sub-Saharan Africa.
\end{abstract}

Keywords: deadlock; equitable and reasonable utilization; equality; fairness; interpretative policy analysis; water law; water allocation; Nile river basin; discourse analysis; distributive policy

\section{Introduction}

A core question in distributive policy is determining how to share water resources equitably and reasonably ([1], pp. 42-44). Article 5(1) of the 1997 United Nations Watercourses Convention (UNWC) defines equitable and reasonable utilization as:

"Watercourse States shall in their respective territories utilize an international watercourse in an equitable and reasonable manner. In particular, an international watercourse shall be used and developed by watercourse States with a view to attaining the optimal and sustainable utilization thereof and benefits therefrom, taking into account the interests of the watercourse States concerned, consistent with the adequate protection of the watercourse" [2].

Article 6(1) of the UNWC lists seven relevant factors and circumstances that the Basin States should take into account when determining an equitable and reasonable water allocation. These factors are:

(a) "Geographic, hydrographic, hydrological, climatic, ecological and other factors of a natural character;

(b) The social and economic needs of the watercourse States concerned;

(c) The population dependent on the watercourse in each watercourse State;

(d) The effects of the use or uses of the watercourses in one watercourse State on other watercourse States; 
(e) Existing and potential uses of the watercourse;

(f) Conservation, protection, development, and economy of use of the water resources of the watercourse and the costs of measures taken to that effect;

(g) The availability of alternatives, of comparable value, to a particular planned or existing use" [2].

Wouters (2013), McIntyre (2016), McCaffrey (2007), and Wolf (1999) state that equitable and reasonable utilization is a fundamental principle of water allocation [2-6]. Most of the international water law agreements contain the principle of equitable and reasonable utilization [2,7], including:

- $\quad$ Article IV of the Helsinki Rules (1996), [8];

- Articles 10.1, 12, 13, 14 and 16 of the Berlin Rules on water resources (2004), [9];

- Article 2.2c of the UN Economic Commission for Europe Convention on the Protection and Use of Transboundary Watercourses and International Lakes (UNECE Water Convention, 1994), [10];

- Articles 4-6, 26 of the Mekong River Basin Agreement (1995), [11];

- Article 2 of the Southern African Development Community (SADC) protocol on shared watercourse systems (1995), [12]; and

- $\quad$ Article 4(1) of the Nile Basin Cooperative Framework Agreement (CFA, 2009), [2].

Practical application of the equitable and reasonable utilization principle to resolve a water allocation dispute is a significant challenge [2,6,13-15]. Wolf (1997) argued that the equitable and reasonable utilization definition is vague and not applicable to specific water conflicts [2]. Moreover, the finalization of the UNWC (1997) took more than 20 years, because there were difficulties in "marrying the legal and hydrologic intricacies" ([2], p. 336). Van der Zaag et al. (2001) explained that the principle is "defined in general terms, and is thus prone to subjective interpretation" ([13], p. 19). Postel (2014) stressed the need to develop more precise criteria [14]. Lankford (2013) argued that the principle and its factors, as is, is misleading to riparian states [15]. Wolf (1997) complemented that the difficulty is aggravated by not having a hierarchy of the factors relevant to equitable and reasonable utilization. None of the factors, nor the water uses, have priority over others ([2], p. 337). In support of the equitable and reasonable principle, Dellapenna (2006), argued that:

"Non-lawyers, particularly engineers and hydrologists, sometimes see this list as a poorly stated equation: if one simply fills in numerical values for each factor, one could somehow calculate a state's share of the water without reference to political or other non-quantitative variables. However, the UN Convention is a legal document that ultimately calls for judgments, and in English, at least, the word "judgment" carries a connotation that the result is not dictated in any immediate sense by the factual and other inputs that the judge relies upon in exercising judgment. Treating this list as an algorithm misses the point entirely" [16].

Unfortunately, whether the principle is treated as a "judgment" or a "poorly stated equation", it remains ambiguous and thus complicates the process of judgment-making or application of an equation [2]. The ambiguity of the equitable and reasonable principle has led to "dialogues of the deaf" amongst water policy communities within certain basins. A "dialogue of the deaf" occurred when policy communities are "unable to resolve a controversial issue [ ... ] As a result, two or more coalitions of actors" engage in prolonged and extensive debates ([17], p. 4). Due to the interdependencies of the actors, the controversial issue remains unresolved "for years on end" ([17], p. 6). Also, the arguments by the different parties cannot be scientifically falsified due to factual support and conflicting belief or value systems. Van Eeten (1999) explained that "dialogue of the deaf" issues are "trans-scientific" ([17], p. 7). The conflicting views are derived from scientific knowledge, but cannot be resolved solely by science. The different arguments are solid, plausible, tried, tested, and perfected over time. Science alone cannot resolve the deadlock [17].

Sabatier (1988) explained that the actors in a "dialogue of the deaf" situation do not listen to one another and tend to "talk past the other" ([18], p. 155). They do not listen because (1) all of the positions 
are well-known, that an actor knows what the other actor will say before they begin to talk; (2) there is no reason for debate because the arguments are well developed and cannot be refuted through science; and (3) "data, evidence, and arguments [are] dependent upon the belief system from which one views the problem" ([17], p. 8). The deadlock may paralyze water allocation processes because any further deliberations do not result in any change or learning.

According to van Eeten (1999), the negative aspects of a "dialogue of the deaf" in public policy are: (1) "paralysis and pendulum swings", in which the pendulum constantly swings from one extreme to another; (2) "institutional sclerosis" ([17], p. 10), in which democratic processes are undermined through inertia and an inability to make decisions [19,20]; (3) "undermines learning" ([17], p. 10), the arguments are irrefutable, established, plausible, and repeated throughout the deliberations; and (4) the process stifles any form of innovation. Facts cannot falsify trans-scientific issues that emanate from belief systems, and thus the actors rarely consider other options [17].

To address "dialogues of the deaf", policy experts have proposed seven strategies ([17], p. 11). Sabatier Jenkins-Smith (1993) and van Eeten (1999) state that these seven proposals have certain predicaments, as explained in this paragraph. The first strategy is to 'choose the better argument'. Actors are encouraged to choose another argument that is more coherent, persuasive, and empirically sound. However, since the arguments contain trans-scientific information, no new polished argument may pass the test. The second strategy is that 'the truth lies in the middle'. To get to the truth would involve simple extrapolation to get to the middle of the two divergent views ([17], p. 13). Nevertheless, the truth may lie in the extremes, in another dimension, or there may be no single truth. This approach is too simple and lacks the basis for addressing the complexity in "dialogues for the deaf". The third strategy is to 'get the big picture'. The proposed argument is to examine the issue using the Hegelian logic (thesis, antithesis, and synthesis). This approach has failed in "dialogues of the deaf" because there are two or more "big pictures" ([17], pp. 13-14). According to Roe (1994), the competing claims provide two or more different puzzles that may interlock but cannot lead to one complete picture [21]. Van Eeten (1999) explained that policy experts use this approach in several models including the welfare economics and multi-criteria analysis. The approach fails to address "dialogues of the deaf" because it entails prioritization and making trade-offs that result in the selection of one competing claim over another. The fourth strategy is 'let politics decide'. This approach leaves the entire decision-making process in the hands of political institutions who make the decision or "decide not to decide" ([17], p. 14). Van Eeten (1999) explained that 'let politics decide' is a partial solution because: (1) a policy made without technocratic support is bound to fail during the implementation stage; (2) political decisions are power decisions that may ignore the truth and validity of competing claims; and (3) politically imposed solutions are not neutral. The fifth strategy is 'bargain for joint gains'. This approach brings the actors together through a consensus-led or mediated process to convert a win-lose situation into a win-win situation ([17], pp. 15-16). Hoppe and Hisschemöller (2018) explained that it is a partial solution, because the actors' logic of rights impairs the logic of gains and losses [22]. The sixth strategy involves 'participation and open discourse' ([1], pp. 16-17). Fischer (1995) stated that "the objective is to initiate and pursue reasoned dialogue and consensus" ([23], p. 20). The excavation process may clarify values and arguments, but might not lead to shared meaning, shared understanding ([17], p. 16), new insights, and shared learning. As a consequence, the main competing positions may remain intact after prolonged and resource intensive participatory processes. Finally, the seventh strategy is to 'just let it be' ([17], p. 17). Sabatier (1988) explained that the 'just let it be' strategy persists until the external driving factors alter power dynamics and lead to change ([18], p. 155). Van Eeten (1999) cautioned that this approach "releases us from the obligation of looking for answers. It claims there are none". This approach is inadequate because it removes 'dialogues of the deaf' from further inquiry and sends a message that there are no solutions to such deadlocks ([17], p. 17).

Van Eeten (1999) proposes defining new agendas as a solution to the 'dialogue of the deaf'. Through van Eeten's (1999) research, competing views were re-casted, made more amenable to analysis, 
deliberation, and negotiation, and four environmental deadlocks were resolved. This approach deconstructs the dialogue through developing a crosswalk from the competing views to scenarios. The actors cannot readily identify their competing views within this new platform. Therefore, they are more open to discuss issues, make trade-offs, and move away from solidified positions.

In this research, we implement the four-step process for defining new agendas:

Step 1 Reconstruct the policy arguments to the debate.

Step 2 Compare and contrast arguments to understand the debate character better.

Step 3 Identify a crosswalk position.

Step 4 Define a new agenda to recast the issue.

In Step 1, this paper adopts the basic definition of equality by evenly distributing the total sum of Nile water discharge between the 11 riparian states. Each country gets less than $30 \mathrm{~mm}$ in depth ([24], p. 30). Though this distribution ensures an equal allocation of the water resources amongst the 11 riparian states, the approach is unfair, as it is based on nine distributive challenges of equality. We discuss these distributive challenges in more detail in Section 3.1.

Step 2 as a process stimulated critical thinking on a fair water allocation method for the Nile Basin. The crosswalk identified in Step 3 consists of:

1. A group-based distributive method (recipient dimension);

2. A value-based distribution method aimed at addressing the needs of all the Nile Basin States (item dimension); and

3. A consensus-based distribution (process dimension).

The paper defines a new agenda, as proposed in Step 4, through recommending a change in the current definition of the recipient of the water resources, the item to be allocated, and the process. These changes widen the scope and ensure that more resources are available for allocation.

The division of the paper is in six parts. The introduction is a summary of research, the problem of interest, and an outline of the rest of the paper. The background section introduces the case study, the relevant Nile basin water agreements, the provisions on equitable and reasonable utilization, and the research problem. In the methods section, the authors introduce the Stone (2002) equality conceptual framework, customized for the Nile Basin, the nine factors that will be used to determine equitable and reasonable utilization, and the interpretative policy analysis approach [1]. The results section provides a detailed account of the findings for each of the nine water allocation methods. The discussion section provides an analysis of the results of applying the conceptual framework in the Nile Basin and the proposed recommendations. The last section provides a brief conclusion.

\section{Background}

This section consists of three parts. First, we introduce the case study: the Nile River Basin. Sub-Section 2.2. explains the incorporation of the principle of equitable and reasonable utilization in the Cooperative Framework Agreement (CFA, 2009). The third sub-section explains the problem that the research seeks to address.

\subsection{The Case Study}

The case study is the Nile River Basin (Figure 1). The Nile, which is $6695 \mathrm{~km}$ long, is the longest river in the world ([10], p. 27). The Nile Basin is 3.18 million square kilometers, which is approximately $10 \%$ and $32 \%$ of the African and European Union landmass, respectively. Eleven riparian states are sharing the basin, namely: Burundi, Democratic Republic of Congo, Egypt, Eritrea, Ethiopia, Kenya, Rwanda, South Sudan, Sudan, Tanzania, and Uganda ([10], pp. 18-27). There are two main tributaries of the Nile River: the White and Blue Nile (Figure 1). The basin is made up of two sub-basins: the Eastern Nile (Egypt, Eritrea, Ethiopia, South Sudan, and Sudan), and the Nile Equatorial Lakes (Burundi, Democratic Republic of Congo, Kenya, Rwanda, South Sudan, Tanzania, and Uganda). 


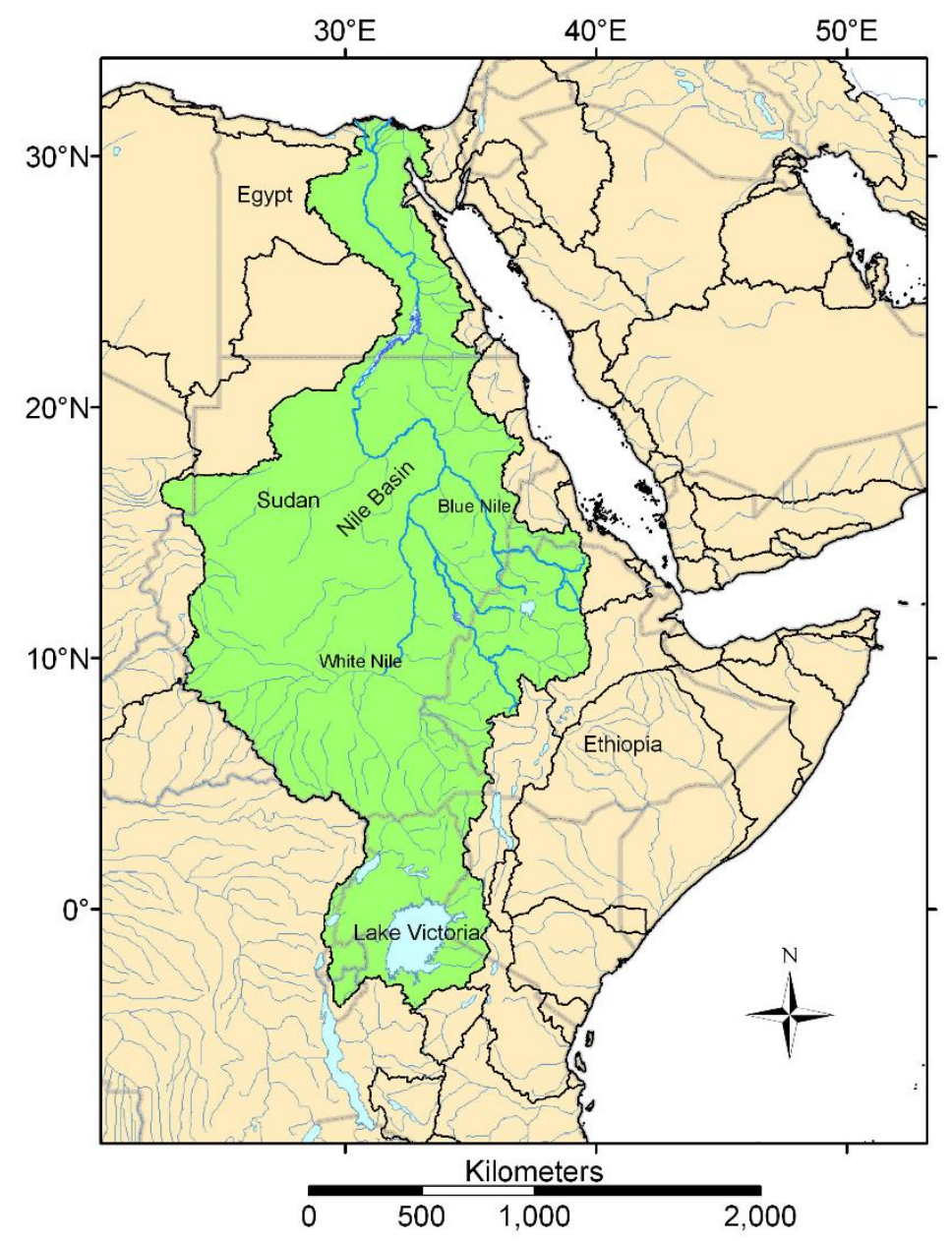

Figure 1. Map of the Nile Basin. The map indicates the two tributaries of the Nile: the Blue and White Nile. Source: Environmental Remote Sensing Laboratory (2018) [25].

The main characteristics of the basin are an uneven distribution of the water resources, low rainfall, high climate variability and diversity, high potential evapotranspiration (PET)—especially in the downstream regions-and high vulnerability to droughts ([24], p. 26). Although the basin is vast, a significant part of the basin does not generate runoff. The basin runoff coefficient of $3.9 \%$ is significantly lower than other rivers of similar length, such as the Amazon [24,26]. A sum of the Nile discharge that is distributed evenly amongst the 11 riparian states is less than $30 \mathrm{~mm}$ in depth ([24], p. 30). There is a high temporal rainfall variability, with some countries having little or no rainfall, while others either have a relatively evenly distributed rainfall or a twin-peaked distribution ([24], pp. 32-33). The PET is high in the desert lands, lowlands, and the basin areas that are near the equator. The PET ranges from $1100 \mathrm{~mm} /$ year (Rwanda and Burundi), $1400 \mathrm{~mm}$ /year (Ethiopian Highlands), and 3000 mm/year (North Sudan). High PETs have resulted in high vulnerability to droughts and increased desertification, especially in Egypt and Sudan ([24], pp. 34-35). Land degradation within many parts of the Nile has reduced the soil moisture-holding capacity, thus increasing water insecurity in most Basin States ([24], p. 35). According to the Nile Basin Initiative (NBI) (2016), Ethiopia, DR Congo, and Tanzania are experiencing severe water access issues, especially in the rural areas. Sanitation is also a significant problem for all of the Nile Basin countries except Egypt, and to a small extent, Rwanda ([27], p. 61). 


\subsection{The CFA (2009) Provisions on Equitable and Reasonable Utilization}

In the Nile Basin, the leading cause of tensions is competing views on the principle of equitable and reasonable utilization [28-30]. The core question is how to allocate the water resources among the Basin States ([1], pp. 42-44). On 22 February 1999, a transitional institution known as the Nile Basin Initiative (NBI) was instituted to develop the basin cooperatively, share the benefits of cooperation, and promote peace and security. The official NBI membership is determined by first having a part of the country in the basin, and second by being a member of the NBI. The NBI comprises 10 member countries and one observer, Eritrea ([24], p. 18).

One of the key mandates of the NBI is to initiate and facilitate a decision-making process that would lead to the development of a cooperative agreement and its institutional setup. This process led to the development of the CFA [31]. Article 4(1) of the CFA (2009) defines equitable and reasonable utilization as:

"Nile Basin States shall in their respective territories utilize the water resources of the Nile River system and the Nile River Basin in an equitable and reasonable manner. In particular, those water resources shall be used and developed by Nile Basin States to attaining optimal and sustainable utilization thereof and benefits therefrom, taking into account the interests of the Basin States concerned, consistent with adequate protection of those water resources. Each Basin State is entitled to an equitable and reasonable share of the beneficial uses of the water resources of the Nile River system and the Nile River Basin" [31].

Article 4(1) of the CFA (2009) was adopted from Article 5 of the 1997 UNWC with a few amendments [32], including: (1) replacing "Watercourse States" with the "Nile Basin States", (2) replacing "international watercourse" with the "Nile River system", and (3) adding the sentence "Each Basin State is entitled to an equitable and reasonable share in the beneficial uses of the water resources of the Nile River system and the Nile River Basin". Also, the CFA (2009) adopts the seven most relevant factors for determining equitable and reasonable utilization from Article 6(1) of the 1997 United Nations Watercourses Convention, namely:

(a) "Geographic, hydrographic, hydrological, climatic, ecological and other factors of a natural character;

(b) The social and economic needs of the watercourse States concerned;

(c) The population dependent on the watercourse in each watercourse State;

(d) The effects of the use or uses of the watercourses in one watercourse State on other watercourse States;

(e) Existing and potential uses of the watercourse;

(f) Conservation, protection, development, and economy of use of the water resources of the watercourse and the costs of measures taken to that effect;

(g) The availability of alternatives, of comparable value, to a particular planned or existing use".

In addition to the seven factors, the CFA (2009) contains these two factors:

(h) "The contribution of each Basin State to the waters of the Nile River system; and

(i) The extent and proportion of the drainage area in the territory of each Basin State" [31].

\subsection{Nile Basin Water Agreements}

There are many Nile Basin water agreements [33]. However, for purposes of this research, we will focus on three primary agreements: the 1929 Exchange of Notes between Egypt and Great Britain (on behalf of its East African colonies), the 1959 Nile water agreement between Egypt and Sudan [34,35] and the CFA (2009). This sub-section will provide a historical background of the Nile water agreements and give a brief explanation of the current position.

In 1929, there was an Exchange of Notes between Egypt and Great Britain on Nile water use for irrigation purposes. Great Britain signed the agreement on behalf of its colonies in East African and Sudan. The 1929 agreement grants Egypt water rights over the Nile, and other countries are 
not permitted to unilaterally initiate water infrastructure projects that reduce the Nile water quantity, water level, or the water arrival date, without prior permission from Egypt. The agreement also adds that Great Britain acknowledges Egypt's "natural and historical rights" ([34], p. 81). In 1959, Egypt and Sudan signed a bilateral agreement to divide the then- 84 billion cubic meters of Nile waters. According to the 1959 agreement, the Nile waters were divided as follows: 55.5 billion cubic meters to Egypt, 18.5 billion cubic meters to Sudan, and 10 billion cubic meters to account for evaporation and seepage (Figure 2). Also, the 1959 agreement provides that any increase in the Nile water flows will be shared equally amongst the two states [34].

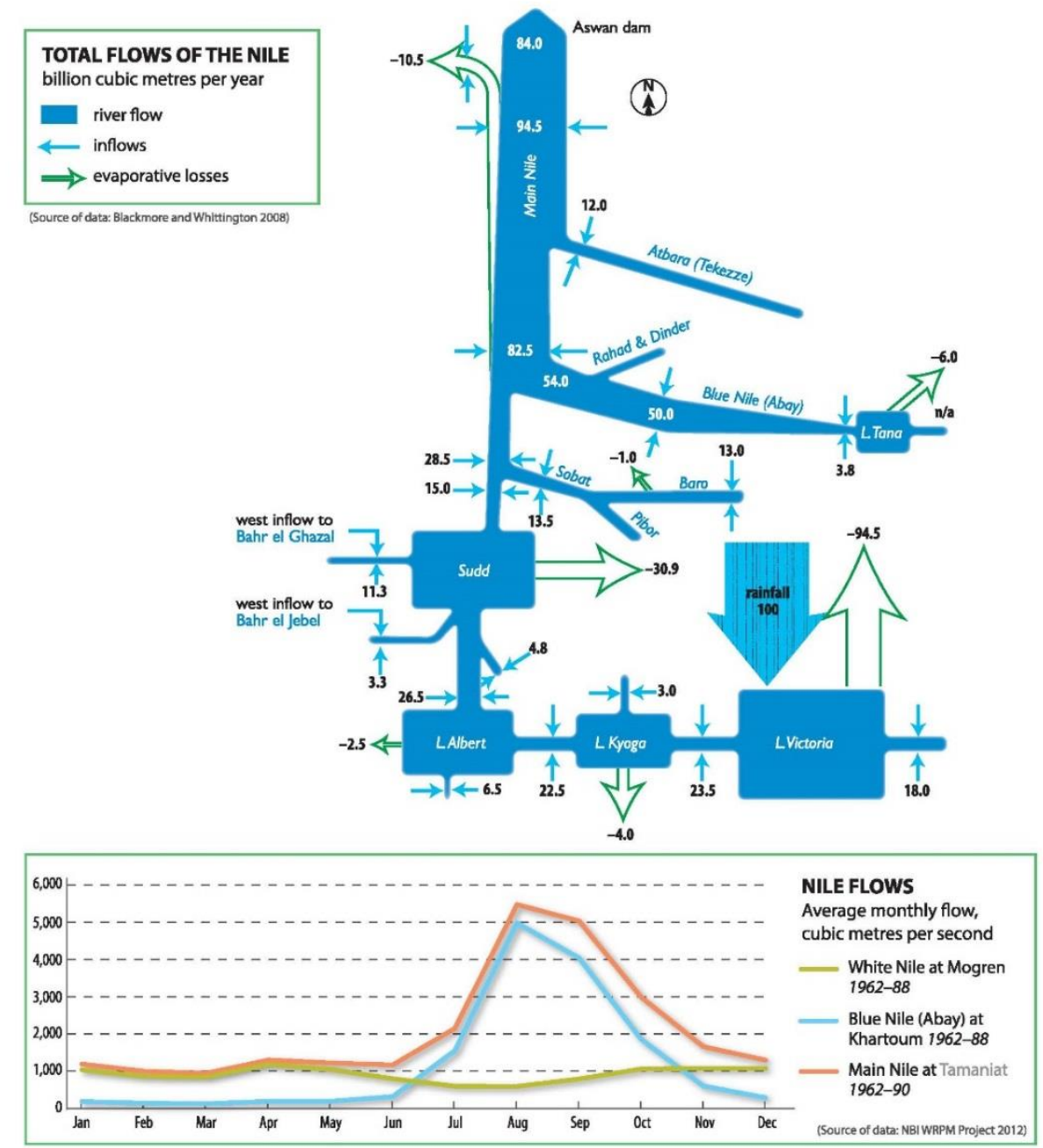

Figure 2. The total flows of the Nile in billion cubic meters per year. The years represented are from 1962 to 1990. The data represented includes river flows, inflows, and evaporative losses. Source (NBI, 2012).

Egypt's attitude toward the 1929 and 1959 agreements, irresolute actions by the other riparian states, and the writings of certain publicists support the view of Egypt's "natural and historical rights" over the Nile. According to Godana (1985), Egypt has consistently held the opinion that the Nile riparian states are perpetually bound by the agreements signed by Great Britain on their behalf [33]. The successor states are bound because the two agreements have not been abrogated through consent as provided in the Vienna Convention on the Law of Treaties. Egypt's belief in their "natural and historical" rights were recognized and supported by Sudan and Great Britain's actions and their local usage of the Nile for centuries ([34], p. 87). Also, Egypt considers any reduction of the Nile water quantity level and time of arrival as a national security issue [36,37]. Some writings from publicists affirm the legitimacy of the 1929 water agreement because it declares prescriptive rights 
and possesses territorial character. Godana (1985) stated that the 1929 agreement was regarded as permanent because it would bind all of the successor states in perpetuity [33]. Vali (1958) added that due to the territorial nature of the 1929 agreement, it binds the successor states [38]. Tanzania and Ethiopia have been consistent in stating that the Nile water agreements do not bind them. However, other riparian states have made ambivalent actions that contradict the position held by Tanzania and Ethiopia. Kenya, for instance, declared that the water agreements should be abrogated or modified by 12 December 1965 (two years after independence) [34]. However, in 2002, the then-Kenyan Minister of Water Development stated that Kenya is bound by the 1929 agreement ([34], p. 4). In light of the above arguments, Egypt has to consent to a new method of Nile river water allocation if the 1929 and 1959 agreements bind the successor states.

The 1929 and 1959 water allocation methods have been challenged as void by some Nile Basin States $[34,39,40]$. Riparian states that are not a party to such a distribution perceive it as discriminatory ([34], p. 52). Since the 1950s, upstream countries challenged the legal status of the 1929 and 1959 agreements ([34], p. 85). Before the independence of the British East African territories, Great Britain expressed the need to revise the agreements to incorporate other riparian states' rights [34,39]. In 1956, Sudan challenged the validity of the 1929 agreement, leading to the negotiation and final signing of the 1959 agreement. In 1960, Tanganyika also challenged the validity of the two water agreements. In 1961, Tanganyika declared to the United Nations Secretary-General that they would be bound by the agreements for two years after independence, and after that regard the agreements as terminated [34]. Afterward, Rwanda, Burundi, Uganda, and Kenya communicated their refusal to be bound by the two agreements $[34,40]$.

On 22 February 1999, the Nile Basin riparian states started a consensus-based decision-making process. In 2009, after 10 years of negotiations, the consensus-based process disintegrated. The disintegration of the CFA consensus-based process was due to three reasons. First, there was no consensus on the provisions of Article 14. This Article required all of the Nile Basin States to jointly manage the Nile water resources in a manner that ensures and sustains water security. Egypt and Sudan were not satisfied with the provisions and requested the addition of a specific provision at the end of Article 14. This specific provision obliged riparian states "not to adversely affect the water security and current uses and rights of any other Nile Basin State" [31]. Their proposal was not accepted by the other Basin States, because they felt that it contravened Article 4 on equitable and reasonable utilization and the shared NBI vision [34,35]. Secondly, the Basin States failed to agree on the notification concept that was proposed by Egypt and Sudan. Upper riparians had entered into the consensus decision-making process with the aim of revoking existing Nile agreements (the 1929 and 1959 agreements) and replacing them with a new basin-wide CFA. Upper riparians viewed the concept of notification as cementing the 1929 agreement provisions on prior notification and thus strengthening the status quo. Finally, when the impasse persisted, the upper riparians stopped the consensus-based process and signed the CFA on 14 May 2010 [34,35].

The CFA is not yet in force, although it has already received the minimum six signatories. It is currently undergoing ratification before it comes into force on the deposit of the sixth ratification or accession instrument with the African Union [31]. Upstream countries still maintain the position that they need a new dispensation that upholds the principle of equitable and reasonable utilization [35]. Downstream countries (Egypt and Sudan) maintain the argument that the new agreement should recognize past agreements, namely the 1929 and 1959 Nile water agreements [34,35].

\subsection{The Research Problem}

The practical application of the equitable and reasonable utilization in the Nile Basin is a significant challenge $[2,6,13-15]$. As explained in the previous sub-section, there are two dominant competing views on how to allocate the Nile water resources. One view is to maintain the status quo, and all of the Nile water resources should be divided between Egypt and Sudan, as provided in the 1929 and 
1959 Nile water agreements $[34,35]$. The other competing view is to allocate the water according to the provisions of the 2009 CFA [31].

The ambiguity of the equitable and reasonable principle in the CFA (2009) has led to "dialogues of the deaf" amongst the Nile Basin States. On February 1999, the Nile Basin governments established the NBI. Since the NBI's establishment, Basin States have been unable to resolve the Nile Basin water allocation challenges. As a result, the upper riparian NBI member states (Burundi, Democratic Republic of Congo, Ethiopia, Kenya, Rwanda, South Sudan, Tanzania, and Uganda) formed a coalition of state actors, and the downstream riparian (Egypt and Sudan) formed another coalition. One coalition (upper riparian states) supports the replacement of the 1959 and 1929 water agreements with the CFA, while the downstream countries seek to maintain the 1959 and 1929 water agreements. The deadlock has led to the two coalitions engaging in extensive debate on how to treat the 1959 and 1929 water agreements in the CFA [35].

The interdependency of the Basin States due to the shared water resource has led to the issue remaining unresolved since the 1960s [33]. Also, the Basin States' arguments cannot be legally and scientifically falsified. The downstream countries arguments support the "vital human needs", "water security" and "historical rights" belief systems [33], and the upstream riparians support the "fair", "equity", and "equality" belief systems [29,30,41]. Reconciling these conflicting belief systems is difficult. Since the competing arguments are "trans-scientific" ([17], p. 7), the Nile Basin dispute cannot be resolved solely by science. Also, the two coalition groups do not listen to each other and tend to "talk past the other" ([18], p. 155). This deadlock in 2009 paralyzed the NBI consensus-led process because the Basin States realized after 10 years of negotiations that further deliberations did not result in any change or learning.

To address the research problem, we propose defining new agendas as a solution to the "dialogue of the deaf" and apply it to the Nile basin context. The proposed method, which we will discuss in detail in the next section, enables the competing views to be re-casted and made more amenable to analysis, deliberation, and negotiation. The four-step approach deconstructs the dialogue, compares and contrasts the principal Nile Basin arguments, identifies a crosswalk position, and defines a new agenda to recast the issue. The crosswalk shifts the attention away from the arguments towards proposed scenarios. The crosswalk may preoccupy the Basin States with the new platform where they cannot quickly identify their solidified positions in the new agenda. The new platform may increase the likelihood of open discussions, trade-offs, and the resolution of the water allocation challenges.

\section{The Methods: Reconstructing the Policy Arguments to the Debate}

This section describes the methods applied in this particular research. The research methods are a combination of the following:

1. Stone's (2002) framework on the concepts of equality (customized for the Nile Basin);

2. Interpretative policy analysis approach; and

3. Factors and circumstances to determine the equitable and reasonable utilization [Article 4(2) of the CFA].

\subsection{Stone (2002) Equality Conceptual Framework}

The paper uses Stone's (2002) framework to expound on the concepts of equality. An illustrative example of the Stone (2002) framework is the distribution of a bittersweet chocolate cake to a public policy class. The teacher counts the number of students present on that particular day and time, and the cake is cut into equal-sized slices and distributed in class. After that, the students challenge the equal distribution, as follows.

1. The solution leaves out the students who were not present on that particular day and time (unequal invitations/equal slices). 
2. The solution does not take into account performance and reward high achievers (equal merit/equal slices; unequal merit/unequal slices).

3. The solution does not take into account the existing hierarchical structure (undergraduates, graduates, teaching assistants, assistant professors, associate professors, full professors, and chair). The higher the position in the hierarchical structure, the more substantial the portion (equal ranks/equal slices; unequal ranks/unequal slices).

4. Men liberationists protest that the women already have higher access to chocolate cakes when baking and attending baking classes. They propose that gender should be the determinant factor for dividing the cake into half for men and half for women. Since men comprise one-third of the class, then they eventually get a more significant share of the cake (equal blocs/unequal slices).

5. Since the class had come from a three-course luncheon, some proposed a more significant share for the students who had a smaller dessert and a smaller share for those who had already taken a substantial share of the dessert (equal meals/unequal slices).

6. Some students are allergic to gluten, milk, and chocolate and others do not like chocolate. These students propose being left out of the distribution (equal value/unequal slices).

7. Business majors propose an equal allocation of forks and no distribution of the cake; every person gets to determine their share depending on how fast they cut and eat the cake (equal forks/unequal slices).

8. Math whizzes propose the use of a hat with the names of all the students to determine who gets the cake, through drawing one ticket. The person whose name appears on the drawn ticket gets the cake since the cake is too small for the whole group (equal chances/unequal slices).

9. Student government activists propose one vote per student, and the elections determine the cake distribution (equal votes/unequal slices).

The distributive solution starts with a simple idea-a same-size slice for everyone. This idea gave rise to nine challenges, which resulted in nine distribution methods. As a consequence, the planned equal treatment resulted in equal slices, but unequal treatment. To address the unequal treatment would result in unequal slices. Therefore, the equal allocation was perceived as unequal treatment, depending on the students' focus.

One key feature of Stone's (2002) Concepts of Equality is the incorporation of both the substantive and process-based aspects of decision-making. Stone (2002) underscores the value of a fair decision-making process; content is not enough to satisfy the fairness principle. Stone (2002) further added that most of the conflicts against a distribution are based on the process and barely on the content. Stone (2002) stated that there is a need to determine whether the decision-making process on who gets what should be determined by representative governments or competition ([1], p. 54).

This paper applies the Stone (2002) conceptual framework to the Nile Basin. Nile waters replace the chocolate cake, and 11 riparian states substitute the students. The distributed item is limited to freshwater (runoff) that flows into the river. The assessment does not incorporate green and grey water in the distribution framework. Also, groundwater (part of blue water) and saltwater lakes, seas, and oceans are not included in the distribution item. Also, the framework does not take account of water innovations such as desalination.

\subsection{Stone's (2002) Equality Conceptual Framework Adapted to the Nile Basin}

As a starting point and in line with Stone's illustrative example, we adopt a basic definition of equality by evenly distributing the total sum of Nile water discharge between the 11 riparian states. Each country will, in this case, get less than $30 \mathrm{~mm}$ in depth ([24], p. 30). Although this distribution ensures an equal distribution of the water resources amongst the 11 riparian states, the distribution is open to criticism, as in Stone's original example. We phrase the nine challenges in Table 1, which are specific to our specific case. 
Table 1. Concepts of equality in Nile water allocation. Customized from Stone (2002).

\begin{tabular}{|c|c|c|c|}
\hline \multicolumn{4}{|c|}{ Concepts of Equality in Nile Water Allocation } \\
\hline \multicolumn{4}{|c|}{ Simple Definition: Same Water Allocation for Each of the 11 Riparian States } \\
\hline \multicolumn{4}{|c|}{ Content about the Case Study Description/Problem } \\
\hline Dimension & Distribution (Nile Basin) & Issue, Stone (2002) & Water Allocation Dilemma \\
\hline \multirow{4}{*}{ Recipients } & $\begin{array}{l}\text { 1. Membership-based } \\
\text { distribution }\end{array}$ & $\begin{array}{l}\text { 1. Membership (the } \\
\text { boundaries of the } \\
\text { community) }\end{array}$ & $\begin{array}{l}\text { unequal member } \\
\text { representation/equal } \\
\text { water allocation }\end{array}$ \\
\hline & $\begin{array}{l}\text { 2. Merit-based } \\
\text { distribution }\end{array}$ & $\begin{array}{l}\text { 2. Merit (based on a } \\
\text { performance and } \\
\text { reward system) }\end{array}$ & $\begin{array}{l}\text { equal merit/equal water } \\
\text { allocation; unequal } \\
\text { merit/unequal water allocation }\end{array}$ \\
\hline & $\begin{array}{l}\text { Rank-based } \\
\text { distribution }\end{array}$ & $\begin{array}{l}\text { 3. Rank (internal } \\
\text { subdivisions of society) }\end{array}$ & $\begin{array}{l}\text { equal ranks/equal water } \\
\text { allocation; unequal } \\
\text { ranks/unequal water allocation }\end{array}$ \\
\hline & $\begin{array}{l}\text { 4. Group-based } \\
\text { distribution }\end{array}$ & $\begin{array}{l}\text { 4. Group (significant internal } \\
\text { cleavages of society) }\end{array}$ & $\begin{array}{l}\text { equal blocs/unequal } \\
\text { water allocation }\end{array}$ \\
\hline \multirow{2}{*}{ Items } & $\begin{array}{l}\text { 5. Need-based } \\
\text { distribution }\end{array}$ & Boundaries of the item & $\begin{array}{l}\text { equal needs/unequal } \\
\text { water allocation }\end{array}$ \\
\hline & $\begin{array}{l}\text { 6. Value-based } \\
\text { distribution }\end{array}$ & Value of the item & $\begin{array}{l}\text { equal value/unequal } \\
\text { water allocation }\end{array}$ \\
\hline \multirow{3}{*}{ Process } & $\begin{array}{l}\text { 7. Competition-based } \\
\text { distribution }\end{array}$ & $\begin{array}{l}\text { 7. Competition (opportunity } \\
\text { as starting resources) }\end{array}$ & $\begin{array}{l}\text { equal water abstraction } \\
\text { opportunity/unequal } \\
\text { water allocation }\end{array}$ \\
\hline & $\begin{array}{l}\text { 8. Consensus-based } \\
\text { distribution }\end{array}$ & $\begin{array}{l}\text { 8. Lottery (opportunity as } \\
\text { statistical chance) }\end{array}$ & $\begin{array}{l}\text { equal chances/unequal } \\
\text { water allocation }\end{array}$ \\
\hline & $\begin{array}{l}\text { 9. } \begin{array}{l}\text { Voting-based } \\
\text { distribution }\end{array}\end{array}$ & $\begin{array}{l}\text { 9. Voting (opportunity as } \\
\text { political participation) }\end{array}$ & $\begin{array}{l}\text { equal votes/unequal } \\
\text { water allocation }\end{array}$ \\
\hline
\end{tabular}

\section{Results: Compare and Contrast Arguments to Understand the Debate Character Better}

This section presents the results and analysis of the nine water allocation methods. Each method is analyzed using the interpretative policy analysis approach. The primary focus is whether the method addresses the nine factors that are relevant in determining an equitable and reasonable water allocation.

\subsection{Member-Based Distribution}

A core question in distributive policy is determining who among the 11 Basin States is a member of the group that gets a share of the water resources ([1], pp. 42-44). The NBI comprises 10 member countries and one observer, Eritrea ([24], p. 18).

Member-based distribution is narrow and fails to address existing water uses, populations that depend on the water, and the effects of the planned use on other basin states. Hamada (2017) stated that a disruption in the Nile water flow might have substantial effects on Egypt because $99 \%$ of its population lives in the Nile Valley and Delta ([34], p. 9). Abdel-Gawad and Khalil (2003) clarified that the Nile Delta population is 35 million, living in an approximate area of $25,000 \mathrm{~km}^{2}$. The primary source of water for Egypt is the Nile [34]. Egypt uses the Nile waters for domestic purposes, irrigation, livestock, fishing, and industrial use. Hamada (2017) explained that the Egyptian water infrastructure linked to the Nile Valley and Delta is massive. It includes canals, barrages, and dams ([34], p. 9). 
The construction of these water infrastructures is along the Nile Valley and Delta, which comprises $4 \%$ of Egypt's total area ([34], p. 10). An alternative source of water would disrupt not only the water quantity and levels but also the already established infrastructure. Such a disruption threatens the life, livelihoods, social fabric, and economy of populations that are heavily dependent on the water resources ([34], p. 9). Swain (2008) stated that Nile waters irrigate half of the 10.2 million hectares of agricultural land [42]. According to Swain (2008), 98.7\% of the irrigated land is in Egypt and Sudan ([42], p. 203). A distribution that fails to take account of these pertinent issues cannot be considered fair from the perspective of the existing users, the population dependent on the Nile waters, and the effects that the distribution would have on the affected Basin States.

Additionally, member-based distribution does not take into account: the contribution of each Basin State to the Nile waters [Article 4(2)(h)], and the "extent and proportion of the Nile drainage area in the Basin State" [Article 4(2)(i)], [31]. According to the NBI (2012), 85\% to $90 \%$ of the Nile flows emanate from the Blue Nile (Ethiopia), and $15 \%$ of the flows emanate from the White Nile (Uganda) ([24], p. 26).

Table 2 provides Nile Basin information on the drainage basin area within the various riparian states and the population living within the Nile Basin. An analysis of the data in Table 2 indicates that there are countries that have more drainage area in the basin, namely Uganda, South Sudan, Sudan, and Rwanda. On the contrary, the Democratic Republic of Congo, Kenya, and Tanzania have a small part of the Nile Basin within their national territory. Looking at the drainage area of the basin within the riparian states as a percentage of the Nile Basin, Sudan, South Sudan, Egypt, and Ethiopia have higher percentages. The percentages of Burundi, the Democratic Republic of Congo, Eritrea, and Rwanda are almost negligible. Egypt, Rwanda, South Sudan, Sudan, and Uganda have the highest populations living in the Nile Basin. In conclusion, the countries with high stakes are Egypt, Rwanda, South Sudan, Sudan, Ethiopia, and Uganda. The Democratic Republic of Congo and Eritrea seem to have the lowest stakes. Countries that may be considered neutral are Kenya, Tanzania, and Burundi. Based on Table 2, the area occupied by the basin in each of the 11 countries, the basin population in every country, and the contribution to the Nile waters is exceptionally diverse.

Table 2. Nile Basin data on drainage basin area within the various riparian states and the population living within the Nile basin (Area falling within the Nile Basin, Contribution of riparian states to the Nile Basin water, \% of drainage area in the Basin States, Total Population, and the percentage of the population living in the basin area). Source: Nile Basin Initiative (NBI) (2012) for the data on the area within the Nile Basin as a percentage of the country area and area within the basin as a percentage of the Nile Basin area ([24], p. 13). NBI (2016) for the 2015 population data and the population within the basin area ([24], p. 53). DR: Democratic Republic.

\begin{tabular}{ccccccc}
\hline \multirow{2}{*}{ Country } & $\begin{array}{c}\text { Area Falling } \\
\text { within Basin }\end{array}$ & $\begin{array}{c}\text { Drainage Area within the Riparian } \\
\text { State as a Percentage of }\end{array}$ & \multicolumn{2}{c}{$\begin{array}{c}\text { Population Living in the Nile } \\
\text { Basin (2015) in Millions }\end{array}$} \\
\cline { 2 - 7 } & $\mathbf{( \mathbf { k m } ^ { \mathbf { 3 } } \mathbf { ) }}$ & \% Country Area & \% Nile Basin Area & Total & In Basin & \% In Basin \\
\hline Burundi & 13,860 & 49.4 & 0.4 & 11.2 & 5.7 & 50.9 \\
DR Congo & 21,796 & 0.9 & 0.7 & 72.1 & 3.9 & 5.4 \\
Egypt & 302,452 & 30.3 & 9.5 & 91.5 & 85.8 & 93.8 \\
Eritrea & 25,697 & 21.1 & 0.8 & 5.2 & 2.2 & 37.8 \\
Ethiopia & 365,318 & 31.9 & 11.5 & 99.4 & 37.6 & 37.8 \\
Kenya & 51,363 & 8.7 & 1.6 & 43.0 & 17.2 & 40.0 \\
Rwanda & 20,625 & 84.0 & 0.6 & 10.5 & 8.7 & 82.9 \\
South Sudan & 620,626 & 97.7 & 19.5 & 12 & 11.9 & 99.2 \\
The Sudan & $1,396,230$ & 74.9 & 44.0 & 36.1 & 31.4 & 87.0 \\
Tanzania & 118,507 & 12.7 & 3.7 & 44.9 & 11.3 & 25.2 \\
Uganda & 240,067 & 99.5 & 7.6 & 34 & 33.6 & 98.8 \\
\hline
\end{tabular}

In summary, member-based distribution is not just distribution. It does not take into account population [Article 4(2)(c)], effects of the use on other Basin States [Article 4(2)(d)], existing and 
potential water uses [Article 4(2)(e)], available alternatives [Article 4(2)(g)], contribution to the Nile waters [Article 4(2)(h)], and the drainage area in each Basin State [Article 4(2)(i)], [31].

\subsection{Merit-Based Distribution}

Merit-based distribution entails the identification and quantification of riparian states' merit, and the design of a reward system for achievements made ([1], pp. 46-48). Whittington et al. (2005) support the need to develop merit-based systems that:

a. Reduce evaporation and seepage by the withdrawal of the Nile waters "as far upstream as possible" ([28], p. 39).

b. Increase hydropower generation by the withdrawal of the Nile waters for irrigation "as far downstream as possible" ([28], p. 39).

c. Reduce evaporation losses by the storage of Nile waters upstream ([28], p. 234).

d. Increase the economic value of the resource by the withdrawal Nile waters "where the user value is greatest" ([28], p. 235).

Despite merit-based distribution being the most promising form of distribution, it has the potential to be the most resisted method. It contravenes Article 4(2)(a)-(e), and (g)-(i) of the CFA. First, the distribution fails to take account of the natural factors such as geography, hydrology, climate, and ecology [Article 4(2)(a)]. High disparities in the Nile Basin call for a merit-based system that takes account of all these natural factors. Some of these natural factors such as climate are highly variable, and it is deeply uncertain whether a merit-based distribution can effectively incorporate these uncertainties. Second, the distribution fails to incorporate the Basin States' social and economic needs [Article 4(2)(b)], [31]. Whittington et al. (2005) explained that $40 \%$ of the water is lost through evaporation and seepage after leaving Lake Tana. Also, high temperatures in the Sudd swamps and the Aswan High Dam Reservoir lead to 50\% and 15\% losses of the Nile river-entering flows, respectively. The proposed solution is to withdraw water for consumptive use before it enters the Sudd swamps and the Aswan High Dam Reservoir. However, this proposed approach fails to consider a whole civilization constructed along the Nile Valley and Delta in Egypt. Third, the merit-based distribution does not take account of the population that depends on the water resources for each riparian state [Article 4(2)(c)], [31]. Whittington et al. (2005) stated that since the hydropower potential of the Blue Nile is at its peak at the border dam, Nile water for irrigation purposes should be limited in Ethiopia ([28], pp. 231-234). However, in some parts of Ethiopia where the Blue Nile flows are dry, food availability is a challenge. Therefore, Ethiopia may argue that the distribution fails to take into consideration the population in Ethiopia who depend on the Nile waters for irrigation purposes. Fourth, the merit-based distribution does not take account of the effects of the proposed options on the other Basin States [Article 4(2)(d)], [31]. Whittington et al. (2005) proposed a reduction in the storage in the Aswan High Dam Reservoir "moving storage upstream into the potential Blue Nile Reservoirs and the Equatorial Lakes" ([28], p. 234). The downstream countries may perceive the solution to be unfair and thus unjust because their populations, agriculture, and economies are heavily reliant on the Nile water resources. Such a distribution would pose a threat to water and human security ([34], p. 9). Fifth, the merit-based distribution does not take account of the existing and potential uses and the costs of the proposed measures [Article 4(2)(e)], [31]. Whittington et al. (2005) and Guariso et al. (1987) argued that the water should be stored upstream due to more favorable volume-to-elevation relationships and lower evapotranspiration [28,43]. Egypt and Sudan may argue that the merit-based allocation fails to take cognizance of the 84 billion cubic meters that are distributed in the 1929 and 1959 agreements. Therefore, there is no available water to distribute.

Sixth, the merit-based distribution does not take account of the availability of comparable alternatives to planned or existing uses [Article 4(2)(g)], [31]. Water footprint experts, desalination experts, and groundwater experts amongst others may challenge the proposed merit-based distribution. Water footprint experts may argue that the distribution is not fair, because it only takes account of 
the blue surface water (runoff). They may propose a more comprehensive distribution that also takes account of groundwater, green water (precipitation found on land, soils or vegetation), and grey water (wastewater from the kitchen, bath, and washing machines). In response, most of the upper riparian state countries may find the proposal to include other water sources apart from runoff unfair, because most international water agreements primarily focus on blue water [3-6]. The upstream countries may also argue that the allocation is unfair because it fails to take account of the groundwater resources. They may further contend that there are considerable groundwater resources in Egypt and Sudan. In response, Egypt and Sudan may argue that some of their groundwater resources are not rechargeable, and therefore this is not a sustainable option. Also, salination is threatening the future usability of their groundwater resources [24]. Seventh, the merit-based distribution does not take account of the contribution that each Basin State makes to the Nile waters [Article 4(2)(h)]. Eight, the merit-based distribution does not take account of "the extent and proportion of the drainage area in the territory of each Basin State" [Article 4(2)(i)], [31]. Article 4(2)(h) and (i) are explained in Section 4.1.

In summary, merit-based distribution does not take into account: natural factors [Article 4(2)(a)], social needs, economic needs [Article 4(2)(b)], population [Article 4(2)(c)], effects of the use on other Basin States [Article 4(2)(d)], existing and potential water uses [Article 4(2)(e)], available alternatives [Article 4(2)(g)], the contribution of a Basin State to the Nile waters [Article 4(2)(h)], and the drainage area in each Basin State [Article 4(2)(i)], [31].

\subsection{Rank-Based Distribution}

Rank-based distribution can be applied when there are hierarchies in a particular group, and the basis of the distributive formula is sub-groups, also known as internal ranks ([1], p. 49). There are many sub-groups within the Nile Basin, sometimes with overlapping membership. The Nile system consists of three sub-systems: the Eastern Nile, the Equatorial Nile, and the Main Nile zone. The Eastern Nile runoff contributes $85 \%$ to $90 \%$ of the annual Nile flows. The Eastern Nile sub-system comprises three sub-groups (catchments): Nile (Abay), Atbara (Takezze), and Baro. The Equatorial Nile sub-system runoff contributes $15 \%$ of the annual Nile flows. The Equatorial Nile sub-system consists of the sub-basin area upstream the Sobat-White Nile confluence ([24], p. 36). The White-Blue Nile confluence at Khartoum, Sudan, is the beginning of the Main Nile zone. The Main Nile produces no runoff. Due to the high temperatures, there is a net loss in the Nile Flows on the lower reach of river Nile. From Khartoum, the main Nile flows downstream to Egypt ([24], p. 37). Figure 2 is an illustration of the Nile flows from the various sub-basins within the Nile system. The total annual Nile flow received at the Aswan high dam is approximately 84 billion cubic meters (BCM).

The three Nile sub-systems are sub-divided into nine catchment areas, namely: Main Nile, Atbara, Blue Nile, White Nile, Baro-Pibor-Sobat, Bahr el Gazal, Sudd (Bahr el Jebel), Victoria-Albert Nile, and Lake Victoria [24]. According to Figure 2, there are high evaporation losses in Lake Victoria and Sudd. However, the high rainfall and the large water body in the Lake Victoria basin ensures a stable annual Nile flow from the Lake Victoria sub-basin. The Equatorial Nile sub-system runoff generates high annual Nile flows, but most of the water is either trapped in four water bodies (Lake Victoria, Lake Kyoga, Lake Albert, and the Sudd) or lost through high evaporation losses [24].

The highest runoff coefficients are 15.9\% (Blue Nile), 7.3\% (Atbara), 7.1\% (Lake Victoria), and $4.4 \%$ (Baro-Pibot Sabot). The Main Nile and White Nile have a $\%$ runoff coefficient with the Main Nile experiencing instream flow losses leading to net losses. The sub-basins with the lowest runoff are Victoria-Albert-Nile (1.0\%) and Bahr el Gazal (2.5\%). The Sudd has a runoff coefficient of $-12.6 \%$ because of net losses from evaporation in the extensive Sudd wetland. The combined Nile system has a runoff coefficient of $3.9 \%$. The evaporation and seasonality of most of the runoff are the major problems facing the Nile Basin. Lake Victoria is the only sub-basin in the Nile system with a relatively stable river flow throughout the year ([24], p. 38).

Since the Nile Basin membership, water usage, reliance on the basin, contribution to the basin water, and the percentage of the population and area in the basin are diverse, the underlying debate 
has been whether all of the countries are entitled to the same share of the water resources. Swain (2002) expressed the view that there are "too many cooks" and "too little broth". The 11 countries are the cooks, and the approximately 84 billion cubic meters (BCM) is the broth. Swain (2002) explained that in the 1960s, the average Nile river flow was approximately 110 billion cubic meters (BCM) ([42], pp. 296). The water quantity has drastically declined over the years. On the contrary, the demand for Egypt's, Sudan's, and all of the Nile Basin countries' freshwater resources has significantly increased [34,42].

An equal distribution would mean that each country receives approximately seven $\mathrm{BCM}$, and the remaining seven billion cubic meters $(\mathrm{BCM})$ are reserved for evaporation losses. Seven billion cubic meters (BCM) is much lower than the current water use in Egypt and Sudan, as illustrated in Figure 3. Such a distribution is unjust because it threatens millions of lives, livelihoods, food security, and the economies of Egypt and Sudan [34,42]. Also, from Figure 3, Egypt has very little or no option to change to other alternative internal renewable water resources.

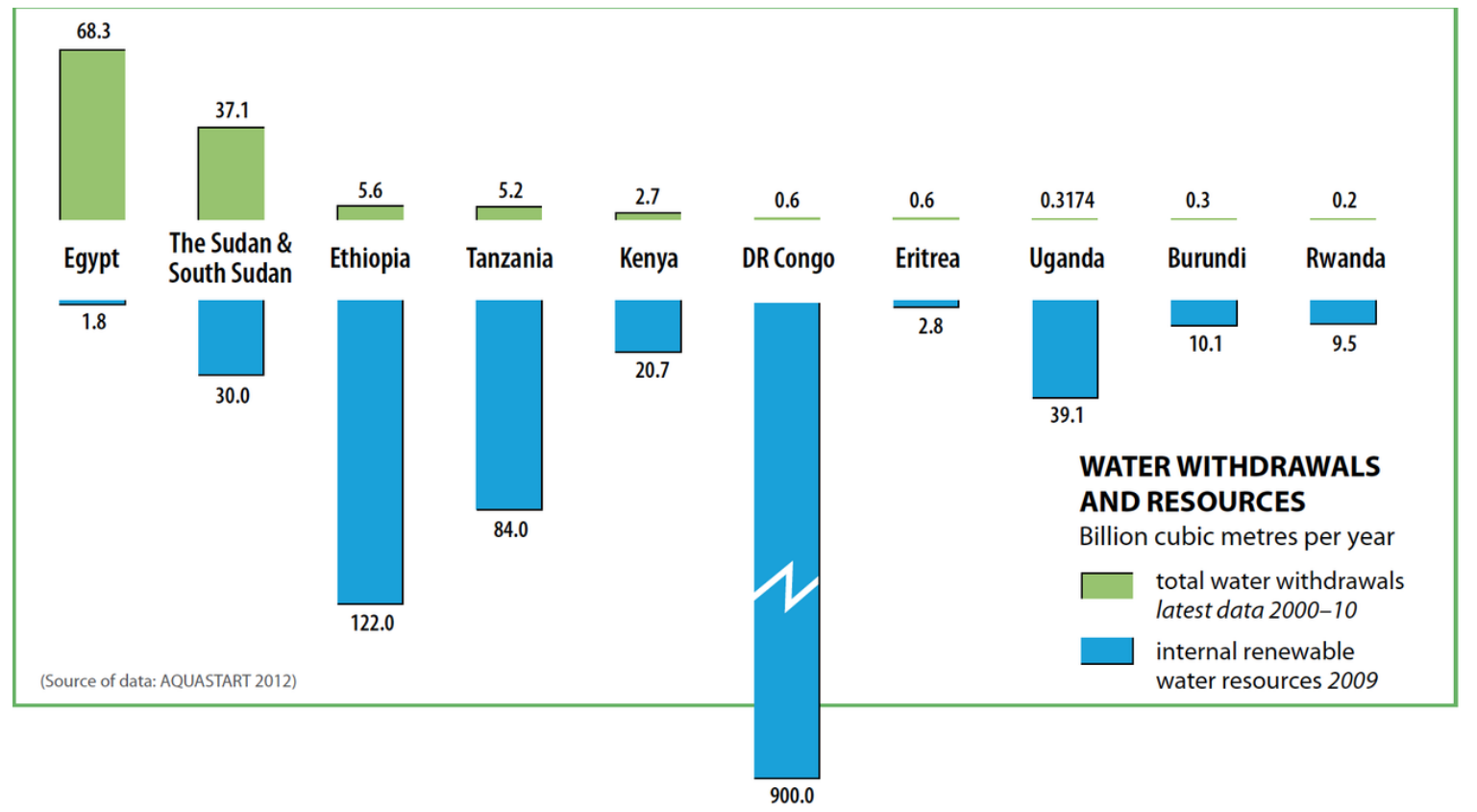

Figure 3. Nile Basin water withdrawals and resources. The top panel of the figure visualizes the total water withdrawals between 2000-2010. The lower panel illustrates the internal renewable water resources by 2009. Source (NBI, 2012) ([24], p. 51).

To address the member-based distribution challenge of high demand (many riparian states) for little and dwindling water resources, Swain (2002) proposed that the focus should be on Egypt, Ethiopia, and Sudan. Swain (2002) added that a basin-wide comprehensive cooperation framework should be a second step and not the core focus ([42], pp. 304-305).

On the contrary, Nicol (2003) proposed an approach that perceives and treats all of the Nile Basin States as part of the solution. Nicol (2003) stated that to achieve "equity", the Nile Basin States should focus less on "cooperative frameworks and joint management of institutions", and more on "delivering tangible and shared development benefits at all levels" ([44], p. 32). Achievement of the tangible results requires mainstreaming Nile Basin water resource actions into the local, national, and regional development plans and processes [44].

Figure 3 demonstrates the availability of immense and untapped water resources. Ethiopia, Tanzania, and Uganda have significant water resources that can be utilized to address the current challenges. Most importantly, the Democratic Republic of Congo has enormous resources within its territory, most of which are not within the Nile Basin. The Nile Basin States need to tap into this immense opportunity by developing joint projects that not only use the Nile Basin water resources but 
draw from other neighboring basins within the riparian states that may be more endowed compared with the Nile.

Rank-based distribution can be challenged based on whether: the established ranks are representative of the sub-group; the rewards mechanism takes account of the diversity; there is an appropriate assignment of riparian states to their respective ranks; and the compensation is equivalent to the rank level ([1], pp. 48-50).

In summary, rank-based distribution is not just distribution. It does not take into account: social, economic needs [Article 4(2)(b)], population [Article 4(2)(c)], existing and potential water uses [Article 4(2)(e)], conservation and environmental factors [Article 4(2)(f)], the contribution of a Basin State to the Nile waters [Article 4(2)(h)], and the drainage area in each Basin State [Article 4(2)(i)], [31].

\subsection{Group-Based Distribution}

Stone (2002) explained that group-based distribution occurs when there are significant divisions that need to be taken into account when determining the distribution modality. She further clarified that the basis of rank-based distribution is performance and achievement, whereas the basis of group-based distribution is specific immutable traits ([1], p. 51). Group-based distribution utilizes typically affirmative action or quotas to level the playing field with the aim of giving the disadvantaged groups equal opportunities to succeed ([1], p. 51).

One key challenge of group-based distribution is the determination of the members of the group. For instance, if group-based distribution considers downstream countries as one group, it is a challenge determining downstream countries in the Nile Basin. Egypt, South Sudan, and Sudan are downstream to Uganda and Ethiopia. However, Uganda is downstream to Burundi, Kenya, Tanzania, Rwanda, and the Democratic Republic of Congo. Uganda, South Sudan, and Sudan are both downstream and upstream countries. Also, it is not clear whether South Sudan falls in the Eastern Nile sub-region, the Nile Equatorial Lakes sub-region, or both. If both, then how can the two group-based distributions ensure that South Sudan does not get a double portion of the water allocation? ([1], p. 51).

The 1929 and 1959 group-based distribution allocations have been perceived as discriminatory [1]. According to Salman (2010), the group-based distribution between Egypt and Sudan foreclosed the future rights of Ethiopia by pre-empting its options of using the Nile waters ([45], p. 352).

Apart from group-based distribution being discriminatory and the difficulty of determining the members, the distribution is not just because it contravenes Article 4(2)(b), (c), (e), (f), and (h) of the CFA. The distribution does not take account of the population that depends on the water resources for each riparian state [Article 4(2)(c)]. In addition, it fails to incorporate social and economic needs [Article 4(2)(b)], potential uses [Article 4(2)(e)], conservation issues [Article 4(2)(f)], and the contribution made by each Basin State to the Nile waters [Article 4(2)(h)], [31].

\subsection{Need-Based Distribution}

The need-based distribution looks at the water allocation problem within the broader scope of a water system and "redefines its boundaries" ([1], p. 52) by considering the water resources and the level of need of each Basin State. Need-based distribution expands water resource boundaries into a more extensive sphere of development that looks at: population, the availability of other water resources, poverty levels, the human development index, the multidimensional poverty index, water scarcity levels, access to water and improved sanitation, and the percentage of the population that can access clean sources of energy (Table 3). However, how to devise a formula that is acceptable by all of the riparian states for determining a need-based distribution in a scarce water basin is a significant challenge [15]. Trade-offs need to be made, and there will be winners and losers. 
Table 3. Nile Basin demographics (poverty levels and Human Development Index). Source: NBI (2012) for the 2011 unconstrained energy deficit per country ([24], p. 169). 2016 United Nations Development Programme (UNDP), Human Development Report (HDR) for 2015 for data on the percentage of population living in poverty, the Multidimensional Poverty Index (MPI) and the Human Development Index (HDI) and rank [46]. There was no data available in the 2016 UNDP HDR for Eritrea and Egypt PPP and Eritrea MPI.

\begin{tabular}{ccccc}
\hline \multirow{2}{*}{ Country } & \multicolumn{2}{c}{ Living in Poverty } & \multicolumn{2}{c}{ Human Development Index } \\
\cline { 2 - 5 } & $\mathbf{2 0 1 6}$ MPI & \% on Less than PPP \$1.90 a Day 2016 & Index (2016) & Rank (2016) \\
\hline Burundi & 0.442 & 77.7 & 0.404 & 184 \\
DR Congo & 0.369 & 77.1 & 0.435 & 176 \\
Egypt & 0.016 & - & 0.691 & 111 \\
Eritrea & - & - & 0.420 & 179 \\
Ethiopia & 0.537 & 33.5 & 0.448 & 174 \\
Kenya & 0.166 & 33.6 & 0.555 & 146 \\
Rwanda & 0.253 & 60.4 & 0.498 & 159 \\
South Sudan & 0.551 & 42.7 & 0.418 & 181 \\
The Sudan & 0.290 & 14.9 & 0.490 & 165 \\
Tanzania & 0.335 & 46.6 & 0.531 & 151 \\
Uganda & 0.359 & 34.6 & 0.493 & 163 \\
\hline
\end{tabular}

Research shows a high likelihood of water scarcity in the Nile basin, coupled with a drastic increase in population $[24,27,29,30,34,41,42,47-50]$. Hamada (2017) outlined a few considerations that support a shift from the current 1959 group-based distribution toward a need-based distribution ([34], p. 56). Hamada (2017) explained that the circumstances have changed, calling for a change in positions. Some of the critical changes are a rapid population increase in all of the countries and climate change [50]. Another change is the increased need for energy [24].

Table 3 results indicate that the poverty levels of most of the countries are extremely high except Egypt, and to a small extent Kenya, although Kenya has a very high level of inequality. These demographic results point toward a significant socio-economic challenge that the riparian states can bridge through development projects, including water infrastructure projects. Arriving at an equitable and reasonable utilization formula that addresses the demographic challenges represented in Table 3 is profoundly complicated.

Table 4 contains data on access to potable water and improved sanitation. From the data, Egypt is the only country that has been consistent in maintaining high water access levels and improved sanitation in the recent past. Ethiopia, DR Congo, and Tanzania experience serious water access issues, especially in the rural areas. Sanitation is a major problem for all of the Nile Basin countries except Egypt and to a small extent Rwanda. Arriving at a distributive formula that meets all 11 states' needs with current water access levels and inadequate access to improved sanitation is very challenging.

Apart from the challenge of all of the riparian states agreeing on a just distribution (within the context of high demand and low supply), the need-based distribution contravenes Article (4)(2)(a), (d)-(i) of the CFA provisions. Need-based distribution does not take into consideration natural factors such as geography, hydrology, climate, and ecology when designing the distribution system [Article 4(2)(a)]. Additionally, the need-based distribution does not take account of the effects of the proposed options on other Basin States [Article 4(2)(d)]. Moreover, need-based distributions barely consider existing and potential uses [Article 4(2)(e)] and conservation and environmental factors [Article 4(2)(f)]. Such a distribution does not take account of the availability of comparable alternatives to planned or existing uses [Article 4(2)(g)]. Also, the distribution does not consider the contribution made by each Basin State to the Nile waters [Article 4(2)(h)]. Finally, it does not take account of the "extent and proportion of the drainage area in the territory of each Basin State" [Article 4(2)(i)], [31]. For instance, the Democratic Republic of Congo has many developmental needs, but the basin area is only $0.9 \%$ of the country. 
Table 4. Nile Basin access to potable water and improved sanitation (percentage of rural and urban populations). Source: NBI (2016) for the 2015 access to potable water and improved sanitation data ([24], p. 61). An estimate of the rural population with access to improved sanitation and drinking water facilities. NBI (2012) for the 2008 data on access to water and improved sanitation ([24], p. 242).

\begin{tabular}{ccccccccc}
\hline & \multicolumn{4}{c}{ Access to Water } & \multicolumn{4}{c}{ Access to Improved Sanitation } \\
\cline { 2 - 9 } Country & $\begin{array}{c}\text { \% of } \\
\text { Rural }\end{array}$ & $\begin{array}{c}\text { \% of } \\
\text { Rural }\end{array}$ & $\begin{array}{c}\text { \% of } \\
\text { Urban }\end{array}$ & $\begin{array}{c}\text { \% of } \\
\text { Urban }\end{array}$ & $\begin{array}{c}\text { \% of } \\
\text { Rural }\end{array}$ & $\begin{array}{c}\text { \% of } \\
\text { Rural }\end{array}$ & $\begin{array}{c}\text { \% of } \\
\text { Urban }\end{array}$ & $\begin{array}{c}\text { \% of } \\
\text { Urban }\end{array}$ \\
\cline { 2 - 9 } & $\mathbf{2 0 0 8}$ & $\mathbf{2 0 1 5}$ & $\mathbf{2 0 0 8}$ & $\mathbf{2 0 1 5}$ & $\mathbf{2 0 0 8}$ & $\mathbf{2 0 1 5}$ & $\mathbf{2 0 0 8}$ & $\mathbf{2 0 1 5}$ \\
\hline Burundi & 71 & 74 & 83 & 91 & 46 & 49 & 49 & 44 \\
DR Congo & 28 & 31 & 80 & 81 & 23 & 29 & 23 & 29 \\
Egypt & 98 & 99 & 100 & 100 & 92 & 93 & 97 & 97 \\
Eritrea & 57 & 53 & 74 & 73 & 4 & 7 & 52 & 45 \\
Ethiopia & 26 & 49 & 98 & 93 & 8 & 23 & 29 & 27 \\
Kenya & 52 & 57 & 83 & 82 & 32 & 30 & 27 & 31 \\
Rwanda & 62 & 84 & 77 & 90 & 55 & 63 & 50 & 59 \\
South Sudan & 53 & 57 & 67 & 67 & 14 & 4 & 54 & 16 \\
The Sudan & 64 & - & 52 & - & 18 & - & 55 & 44 \\
Tanzania & 80 & 48 & 45 & 77 & 21 & 8 & 32 & 31 \\
Uganda & 91 & 65 & 64 & 73 & 49 & 17 & 38 & 77 \\
\hline
\end{tabular}

In summary, need-based distribution is not just distribution. It does not take into account: natural factors [Article 4(2)(a)], effects of the use on other Basin States' [Article 4(2)(d)] existing and potential water uses [Article 4(2)(e)], conservation and environmental factors [Article 4(2)(f)], available alternatives [Article 4(2)(g)], contribution of a Basin State to the Nile waters [Article 4(2)(h)], and the drainage area in each Basin State [Article 4(2)(i)], [31].

\subsection{Value-Based Distribution}

Value-based distribution is a shift from the standardized value of the item toward a customized value ([1], p. 53). Currently, the distribution of the Nile water is between Egypt and Sudan. Both the 1959 and the 1929 agreements make provisions for the renegotiation of the water allocation provisions, especially if the water increases, reduces, or they agree to share the water with another riparian state.

There are many other opportunities in the Nile Basin for value-based distribution. Table 5 indicates the value of all of the Nile Basin countries' arable land and hydropower potential. Ethiopia and Sudan have vast arable land that can be used to grow food crops that could be sold to the other Basin States. The challenge facing most of the Nile Basin countries is water. There is vast arable land with very low irrigation potentials. Egypt has a unique challenge; it has limited arable land that is $1,634,000 \mathrm{~km}^{2}$ less than its irrigation potential. Egypt is about to exceed its current irrigation potential; its main challenges are the availability of arable land and freshwater resources. Ethiopia has a high irrigation potential, and $94.5 \%$ remains untapped. Sudan and Ethiopia have a large surface area of arable land. Sudan's primary challenge is water; its irrigation potential is too low compared to the arable land. Sudan has utilized $100 \%$ of its irrigation potential. According to Table 5, Ethiopia, Kenya, Rwanda, and Burundi could enter into a value-based distribution where they use their untapped irrigation potential and supply food to other countries such as Sudan and Egypt. There are immense opportunities for Ethiopia, Sudan, DR Congo, Rwanda, and Kenya to use other sources of water to grow crops for the basin.

Apart from arable land, hydropower potential may form the basis for a value-based distribution. Table 5 provides information on the hydropower potential of the Nile Basin countries by providing data on the percentage of the rural and urban population with access to electricity, the countries' respective hydropower potentials, and the hydropower installed. The hydropower potentials of DR Congo and Ethiopia are high; they have the potential to supply energy to the entire basin and the African continent. Kenya and Tanzania also have high hydropower potentials. Apart from Egypt, 
most of the Nile Basin countries have not tapped more than $90 \%$ of their hydropower potential (low electricity consumption rates). A value-based distribution would focus on identifying which of these countries would provide better value for money in generating hydropower for the entire basin.

Table 5. Nile Basin data on land, irrigation, and hydropower (area per country, access to arable land, irrigated area, irrigation potential, the percentage of the rural and urban population with access to electricity, hydropower potential, and hydropower installed). Source: NBI (2016) for the 2012 access to access to electricity (\% of the population) in urban and rural areas and the electricity net consumption (KWh/c), 2010 ([24], pp. 62-63). NBI (2012) for the 2008 data on access to water and improved sanitation ([24], p. 242). African Development Bank, Policy for Integrated Water Resources Management (2000) for the irrigation and hydropower potential of the Nile Basin countries [51].

\begin{tabular}{|c|c|c|c|c|c|c|c|c|}
\hline \multirow[t]{2}{*}{ Country } & \multirow[t]{2}{*}{$\begin{array}{c}\text { Area } \\
\left(1000 \mathrm{~km}^{2}\right)\end{array}$} & \multirow[t]{2}{*}{$\begin{array}{c}\text { Arable } \\
\text { Land } \\
\text { (1000 ha) }\end{array}$} & \multirow[t]{2}{*}{$\begin{array}{l}\text { Irrigated } \\
\text { Area } \\
\text { (1000 ha) }\end{array}$} & \multirow[t]{2}{*}{$\begin{array}{l}\text { Irrigation } \\
\text { Potential } \\
(1000 \text { ha) }\end{array}$} & \multicolumn{2}{|c|}{$\begin{array}{l}\text { \% of Population } \\
\text { with Access to } \\
\text { Electricity (2012) }\end{array}$} & \multirow[t]{2}{*}{$\begin{array}{l}\text { Hydropower } \\
\text { Potential } \\
\text { (MW) }\end{array}$} & \multirow[t]{2}{*}{$\begin{array}{l}\text { Electricity Net } \\
\text { Consumption } \\
(\mathrm{KWh} / \mathrm{c}), 2010\end{array}$} \\
\hline & & & & & Rural & Urban & & \\
\hline Burundi & 26 & 770 & 14 & 185 & 1.2 & 58.5 & 1366 & 24.7 \\
\hline DR Congo & 2345 & 6930 & 11 & - & 5.7 & 36.3 & 530,000 & 107.3 \\
\hline Egypt & 1001 & 2800 & 3266 & 4434 & 100 & 100 & 3210 & 1567.3 \\
\hline Eritrea & 118 & - & 28 & - & 7.5 & 100 & - & \\
\hline Ethiopia & 1104 & 11,300 & 190 & 3637 & 6.7 & 58.2 & 162,000 & 50.9 \\
\hline Kenya & 583 & 4000 & 67 & 352 & 7.7 & 61.5 & 30,000 & 150.3 \\
\hline Rwanda & 26 & 8504 & 4 & 160 & 3.4 & 12.2 & 3000 & 30.3 \\
\hline South Sudan & - & - & - & - & 17.7 & 62.1 & - & 140.8 \\
\hline The Sudan & 2506 & 12,920 & 1946 & 1946 & 3.6 & 46.4 & 1900 & 89.0 \\
\hline Tanzania & 945 & 2100 & 190 & 828 & 8 & 71 & 20,000 & 64.5 \\
\hline
\end{tabular}

Ethiopia may propose a value-based distribution that takes account of the recent construction of the Grand Ethiopian Renaissance Dam (GERD). Whittington (2014) highlighted critical discourses on the GERD. For Ethiopia, the central discourse is: the dam will provide hydroelectricity power for most of the riparian states and distribute it through the interconnection lines ([52], p. 600). Based on estimates, $80 \%$ of the benefits of the new dam will be energy-related. Table 5 demonstrates that in the Nile Basin, the upstream countries have higher and untapped hydropower and irrigation potentials. Also, the arable land in Sudan and Ethiopia is vast; sufficient water resources to irrigate the land are lacking. Table 5 further indicates that Egypt and Sudan have almost exhausted their irrigation and hydropower generation potential. DR Congo and Ethiopia have the most extensive potential. The energy projects in these two countries are sufficient to supply energy to all of the Nile Basin countries [24]. Also, there will be an estimated saving of three billion cubic meters (BCM) per annum on the evaporation losses because Ethiopia is on the Blue Nile gorge with colder temperatures ([52], pp. 598-600). The riparian states can realize the savings after the dam is filled ([52], p. 600). Moreover, there will be reduced surface evaporation because the dam is built on the Ethiopian highlands as opposed to the lowlands in Sudan and Egypt ([52], pp. 598-600). Despite having many dams along the Nile river (Figure 4), it will be the second dam to provide over-year storage (other dams have lower storage capacities) ([52], p. 600). 


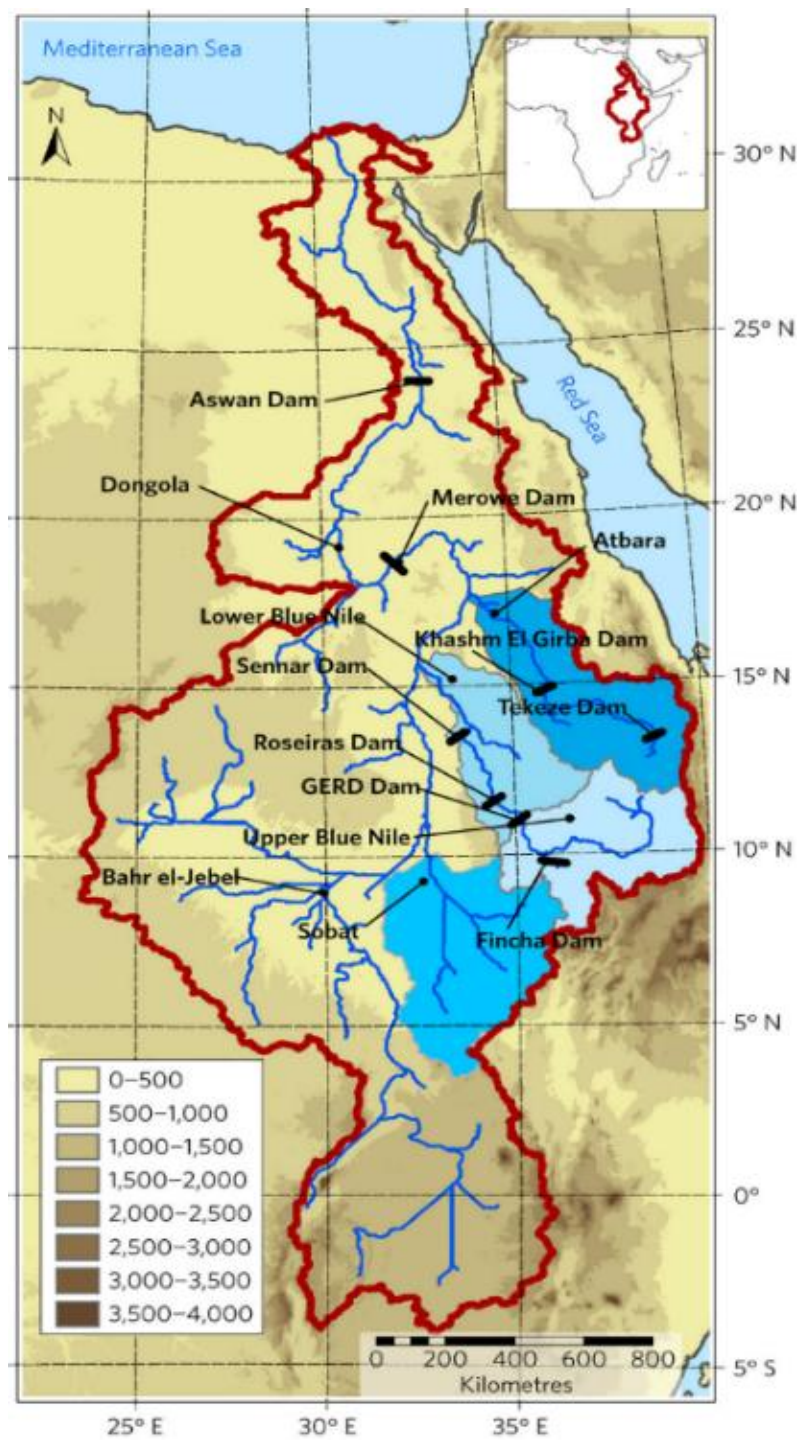

Figure 4. Map of the Nile Basin that identifies the location of some of the critical dams. The map includes the old dams such as the Aswan dam and also new dams such as the Grand Ethiopian Renaissance Dam (GERD), which is still under construction. Source: Siam (2017), [53].

According to Whittington (2014), the GERD may lead to improved upstream Blue Nile regulation, resulting in increased energy production by the Sudan dams (Merowe, Sennar, and Roseires) ([52], p. 600). Additionally, the floods downstream will reduce, and as a consequence, reduce the flood-related hazards and risks [54]. Also, the GERD will reduce siltation and sediment control costs for Sudan [55]. The improved upstream regulation will also increase river navigation opportunities. Finally, Ethiopia has undertaken to pay all the costs of building the dam. Sudan will not pay the dam construction costs and will enjoy the benefits of improved upstream regulation of the Blue Nile ([52], p. 601).

Due to the immense value of the GERD, Egypt, Sudan, and Ethiopia may renegotiate the current 1959 agreement group-based distribution toward a customized value-based distribution. To support their position, they may refer to the provisions of the "agreement on Declaration of Principles" that was signed on 23 March 2015 by Egypt, Ethiopia, and Sudan in Khartoum, Sudan [56].

Stone (2002) cautioned that value-based distributions have resulted in the most social policy conflicts. She further explains that value-based distributions primarily rely on the strength of the relationships and the ability to tailor the allocation to address the values. Value-based distributions 
have proven to be hard to sustain because values are subjective, and therefore, the probability of a shared meaning of equity on customized value-based distributions is usually very low ([1], p. 54). However, the redefinition of the value of water in the Nile Basin will largely depend on the effects of the proposed allocation on existing, planned, and potential uses. Egypt and Sudan may argue that the 2015 agreement did not nullify previous water agreements. Therefore, the 1959 agreement still stands, and any water allocation changes should not reduce the already agreed 55.5 BCM to Egypt, 18.5 BCM to Sudan, and 10 billion cubic meters to account for evaporation and seepage. Also, according to the 1929 agreement, Ethiopia needs to seek Egypt's consent on the dam-filling plan so that it does not adversely affect the downstream countries.

Value-based distribution has the potential to be resisted as an unjust distribution because it contravenes Article 4(2)(b)-(e), and (i). First, the distribution fails to incorporate the Basin States' social and economic needs [Article 4(2)(b)]. Second, the distribution does not take account of the population that depends on the water resources for each riparian state [Article 4(2)(c)]. Third, the distribution does not take account of the effects of the proposed options on other Basin States [Article 4(2)(d)]. Fourth, the distribution does not take account of the existing uses [Article 4(2)(e)]. Fifth, the distribution does not take account of the "extent and proportion of the drainage area in the territory of each Basin State" [Article 4(2)(i)], [31].

\subsection{Competition-Based Distribution}

The focus of competition-based distribution is ensuring less regulation of water use, thus giving each country the freedom to utilize and develop the water resources within their boundaries, with no restrictions.

Competition-based distribution does not take into consideration the existing and potential uses [Article 4(2)(e)], [31]. The existing uses are the major Nile Basin reservoirs in Egypt, Sudan, Ethiopia, and Uganda, as illustrated in Figure 4. These Nile Basin reservoirs are: Owen Falls (Uganda), Jebel Aulia (Sudan), Sinnar (Sudan), Roseries (Sudan), Kashim Al Girba (Sudan), Aswan High Dam (Egypt), Merowe (Sudan), Tekezze (Ethiopia), and the Grand Renaissance Dam (under construction in Ethiopia) ([50], p. 61).

In competition-based distribution, upstream riparian states have an unfair hydrological advantage over downstream countries. At present, out of the 84 billion cubic meters (BCM) of the Nile water flows that reach Lake Nasser, Egypt, only 0.4 BCM is discharged into the Mediterranean Sea [50,57]. Moreover, Egypt imports half of its food grains, because internal crop production is not sufficient to feed its population. Also, the Toshka land reclamation project in the Western desert is planned to irrigate the desert land and resettle millions of people with limited Nile water resources [34]. The Grand Renaissance Dam is intended to have a storage capacity of approximately 74 BCM [50,58]. If the competition-based distribution is applied, then due to hydrological advantage, Ethiopia may draw $74 \mathrm{BCM}$, leaving only $10 \mathrm{BCM}$ to flow downstream. The Main Nile loses $10 \%$ of its water to evaporation, leaving approximately 9 BCM (12\% of the current use) for Egypt and Sudan. Application of this distribution, with no safety measures, would result in devastating effects downstream.

Second, competition-based distribution is unjust, because there is unequal competition between the Basin States that have more financial resources to exploit the water resources with other states that barely have the resources to construct mega hydrological projects [Article 4(2)(b)], [31,34]. Third, the competition-based distribution does not take into account natural factors, droughts, climate change, and other natural disasters [Article 4(2)(a)], [31]. One example of a competition-based distribution reservoir that would have led to more favorable outcomes if natural factors were considered is the Aswan High Dam. The Aswan High Dam in Egypt was constructed in 1970 on the Main Nile with an original storage volume of $169 \mathrm{~km}^{3}$. The Aswan High Dam is primarily responsible for regulating the Nile water flows that used to be extremely high in August and September, and relatively low in other months. The dam regulates the flow through limiting discharges [59]. Two significant drawbacks of the dam are the large volumes of water losses due to evaporation, and the extreme losses in land 
fertility because the silt is no longer deposited in the Nile Valley (trapped inside the dam). If the Aswan High Dam were constructed upstream in Ethiopia, there would have been more benefits and fewer drawbacks [28].

Moreover, the competition-based distribution does not foster peace and cooperation. The distribution fails to take account of the population [Article 4(2)(c)], pollution, and water conservation issues [Article 4(2)(f)], and the effects of the proposed options on the other Basin States [Article 4(2)(d)]. Also, the distribution fails to take account of the availability of comparable alternatives to planned or existing uses [Article $4(2)(\mathrm{g})]$.

In summary, competition-based distribution is just if the resource is finite. In a water-scarce basin, the competition-based distribution does not translate into fair water allocation, because it contravenes all nine factors, as listed in Article 4(2) [31].

\subsection{Consensus-Based Distribution}

Bressen (2007) explains that in consensus decision-making, all of the Basin States must agree for any water policy to be adopted [60]. On 22 February 1999, the Nile Basin riparian states started a consensus-led process spearheaded by the NBI. After 10 years of negotiations, the Basin States were unable to reach consensus, and as a consequence, the upper riparians began the process of signing the CFA. On 28 February 2011, the CFA had the minimum number of signatories when Burundi appended its signature. After that, the process of having it ratified begun. To date, Ethiopia, Tanzania, and Rwanda have ratified the CFA. On the deposit of the sixth instrument of ratification/accession with the African Union, the CFA will enter into force.

However, if the CFA does come to force, Egypt and Sudan may argue that: (1) they are not a party to the CFA; (2) no consensus was reached on Article 14, and (3) no consensus was reached on the concept of notification. They would further argue that the distribution represented in the CFA does not bind them. Their argument will mainly focus on the disintegrated consensus-based process. A future Nile Basin water allocation distribution may address all of the factors listed in Article 4(2) of the CFA, but may fail to meet the process requirements of a consensus-based distribution, and thereby be deemed unjust [31].

\subsection{Voting-Based Distribution}

Voting-based distribution is through an established system that determines who wins and who loses with the purpose of ensuring an equal statistical chance of winning. Voting is beneficial because it: enables actors to express their preferences, facilitates reaching a compromise when there is an impasse, legitimizes decisions, creates a perception that all of the actors have equal standing, and the inputs and decisions are representative. Democrats may argue that this solution is fair because it gives every Basin State an equal vote. However, the downstream countries may argue that they are a minority, equal votes are not the solution, and only a consensus approach would resolve the impasse. On the other hand, the upstream countries may argue that a consensus approach is a political tool used to stall any process and maintain the status quo. All of the parties may finally opt for a weighted voting system to resolve the impasse.

Voting, whether weighted or unweighted, has its challenges. Steelman et al. (1997) explained some of the challenges of voting in the context of natural resource policymaking. These challenges include ambiguous voting decision rules, biased representation, a high chance of questioning decisions, unequal and variable standing, and less attention given to scientific knowledge ([61], p. 80).

Voting-based distribution may also be considered unjust because the voters may not take into account any of the Article 4(2) factors before voting [31]. Swain (2002) argued that the simple majority vote system for all of the Nile basin countries will not work [42]. Swain (2002) proposed groups based on existing and potential uses [Article 4(2)(e)], the contribution made by each Basin State to the Nile waters [Article 4(2)(h)] and the "extent and proportion of the drainage area in the territory of each Basin State" [Article 4(2)(i)], [31]. Therefore, according to Swain (2002), countries with higher stakes to 
gain or lose such as Egypt, Sudan, and Ethiopia should first seek solutions to the sub-basin challenges before establishing a voting-based distribution for the entire Nile Basin.

\section{Discussion}

This section comprises four parts. First, a consolidation of the critical findings of the results section on the nine definitions of equity and an identification of a crosswalk. Then, a discussion of the challenge with the identified crosswalk. After that, a definition of a new agenda about the three dimensions of equity: the recipients (member-based, merit-based, rank-based, and group-based distributions); the items (need-based and value-based distributions); and the process (competition-based, consensus-based, and voting-based distributions). Finally, an explanation of the replicability of the research approach to other basins with similar challenges.

\subsection{Identify a Crosswalk: Choosing a Nile Basin Water Allocation Method}

One key outcome of the research findings in Section 3 of this paper was the lack of a shared meaning on how to address the Nile Basin water allocation challenges. It was also evident that many sets of discourses on how to address the Nile Basin equity challenge exist. Some of these discourses seem to be slowly developing into dominant discourses. Unfortunately, the process is haphazard and slow. Policy analysts could play a significant role in connecting the sets of discourses that have sound scientific backing with practice. Policy analysts may support the process of reframing and develop a shared meaning, and if need be, the suppression of other divergent knowledge sets and alternative discourses that may not lead to fair water allocation.

Some methods incorporated more factors than others (Table 6). The assessment does not provide a full account of the "process" dimension. Such an account would require more detailed analyses of Nile Basin processes and what the negotiators and decision-makers took into account before developing a specific policy document. The CFA process is analyzed because it forms the basis of this paper. However, many Nile Basin processes may need further and more in-depth analyses to be able to assess process-based distribution concretely (whether competition, consensus or by voting).

Table 6. Summary of the assessment results of the nine water allocation methods.

\begin{tabular}{|c|c|c|c|c|c|c|c|c|c|c|}
\hline \multicolumn{2}{|c|}{ Concepts of Equality in Nile Water Allocation } & \multicolumn{9}{|c|}{ Article 4(2) of the Nile Basin CFA } \\
\hline Dimension & Distribution Method & $\mathrm{a}$ & $\mathrm{b}$ & c & $\mathrm{d}$ & e & $\mathrm{f}$ & $\mathrm{g}$ & $\mathrm{h}$ & $\mathrm{i}$ \\
\hline Recipients & $\begin{array}{c}\text { Membership-based distribution method } \\
\text { Merit-based distribution method } \\
\text { Rank-based distribution method } \\
\text { Group-based distribution method }\end{array}$ & $\begin{array}{l}\sqrt{ } \\
\sqrt{ } \\
\sqrt{ }\end{array}$ & $\sqrt{ }$ & & $\begin{array}{l}\sqrt{ } \\
\sqrt{ }\end{array}$ & & $\begin{array}{l}\sqrt{ } \\
\sqrt{ }\end{array}$ & $\begin{array}{l}\sqrt{ } \\
\sqrt{ }\end{array}$ & & $V$ \\
\hline Items & $\begin{array}{l}\text { Need-based distribution method } \\
\text { Value-based distribution method }\end{array}$ & $\sqrt{ }$ & $\sqrt{ }$ & $\sqrt{ }$ & & & $\sqrt{ }$ & $\sqrt{ }$ & $\sqrt{ }$ & \\
\hline Process & $\begin{array}{l}\text { Competition-based distribution method } \\
\text { Consensus-based distribution method } \\
\text { Voting-based distribution method }\end{array}$ & & & . & . & & & & & \\
\hline
\end{tabular}

The results and analysis section assesses nine competing definitions of equity. Table 6 is a summary of the outcomes of the assessment. The ticks in the table indicate the factors taken into consideration in each water allocation method.

The central research question is: with all these competing methods of equity, which one translates into equitable and reasonable utilization, in the context of the Nile Basin? This research question is further broken down into the following sub-questions:

1. Across all methods: Which equitable and reasonable utilization factors are not taken into account in the various water allocation methods? (Results and Analysis Section) 
2. Recipients: Who are the eligible Nile Basin recipients? What criteria make the identified Nile Basin recipients eligible? Which recipients does this research recommend? (Discussion Section)

3. Item: What is being allocated? How do Nile Basin players define or envision the item being allocated? What kind of item does this research recommend? (Discussion Section)

4. Process: What decision-making processes have been used so far in the Nile Basin to determine equitable and reasonable utilization? What kind of process does this research recommend? (Discussion Section)

Table 6 demonstrates that there is no right or wrong definition of equity; none of the nine water allocation methods met Article 4(2) of the CFA requirements. Since none of the nine definitions met the equity requirements as set out in the CFA, then there is the need to consider combining different options to develop a combined distributive method. Merit-based distribution is the most promising to a rational decision-maker. However, it was the least preferred option after competition-based distribution, when analyzing the various discourses. It entails drastic reforms, thereby reducing the likelihood of adoption.

Apart from merit-based distribution, the other two forms of distribution that may not be successful, if advocated for as a sole distributive method are the membership-based and competition-based distributions. Membership-based distribution is intuitively a robust solution, at face value, because an equal-slice solution for every member "looks and feels" ([1], p. 56) equal. However, when subjected to further scrutiny, it does not pass the test. There is a link between the membership-based solution and a simple majority voting-based distribution. If every member state has one vote, then there is a high likelihood that the decisions made by such an institution will contravene most of the factors outlined in Article 4(2)(b).

The competition-based distributive method, on the other hand, is preferred by most member states as the most straightforward and best internal solution to the problem. However, when water resources are shared and scarce, competition-based distribution is not recommended, because it may lead to land degradation and overexploitation of the water resources. Competition-based distribution barely takes into account any of the provisions of Article 4(2)(b). Moreover, natural factors, hydrology, and the surface area of the drainage basin in a particular Basin State may limit a riparian state's competitive actions.

Therefore, based on Table 6, the most preferred distributive method should incorporate the following distributive methods in the final solution:

1. Recipients Dimension: A group-based distributive method.

2. Items Dimension: A value-based distribution. Need-based distribution does not help resolve the scarcity issue. However, a value-based distribution that ensures that the benefits are used to address the needs is preferable.

3. Process Dimension: A consensus-based distribution, with the possibility of using the political reasoning model when the countries reach an impasse (process dimension). Since there is a link between recipients and item dimensions, if the recipients are correctly identified, and the item focus is selected, then the dangers of process bias are reduced.

In the subsequent sub-sections, the paper focuses on outlining the challenges of the identified crosswalk, defining a new agenda for the three dimensions of equity, and identifying the replicability of the research in other river basins.

\subsection{The Challenge with the Crosswalk}

Apart from the fifth factor (existing and potential uses), all of the other factors were incorporated, with some factors considered more than other factors, based on the number of times each factor was incorporated. Other factors that also received little attention in the nine distributive methods were: the population that depends on the water resources for other riparian states [Article 4(2)(c)], 
the contribution made by each Basin State to the Nile waters [Article 4(2)(h)] and "the extent and proportion of the drainage area in the territory of each Basin State" [Article 4(2)(i)]. Basin States' social and economic needs [Article 4(2)(b)], and the effects of the proposed options on other Basin States [Article 4(2)(d)] are the two factors that are between the most considered factors and the least considered factors [31]. The first factor relating to "geographic, hydrographic, hydrological, climatic, ecological and other factors of a natural character" was regarded as the most important in determining equitable and reasonable utilization \{Article 4(2)(a)]. The second most-considered factors are conservation issues [Article 4(2)(g)] and the availability of comparable alternatives to planned or existing uses [Article 4(2)(g)].

According to International Law, there is no hierarchy in the nine factors for determining equitable and reasonable utilization; they need to be considered as a whole [2]. Table 6 demonstrates how difficult it is for any given basin to develop a water allocation method that incorporates all nine factors as a whole. The best option that may incorporate eight factors is a combination of four distribution methods. This option, as discussed earlier, is a group value consensus-based method that ensures that the value-based method aims to address the needs of the Basin States (need-based distribution). The problem with this proposed water allocation method is its inability to incorporate Article 4(2)(e).

According to Table 6, all of the distributive methods were unable to incorporate the fifth factor on existing and potential uses and the costs of the proposed measures [Article 4(2)(e)], which is a significant limitation to our proposed water allocation method. The paper infers that Article 4(2)(e) cannot be incorporated into any of the allocation methods because it defeats the primary purpose of any allocation. The Basin States can only allocate if they have something to allocate. Allocation of all of the Main Nile water resources through previous agreements and existing uses defeats the need to dedicate time, money, and other resources to develop an allocation method through an extensive and all-inclusive participatory process when all the players know beforehand that there is nothing to distribute. The $84 \mathrm{BCM}$ is already allocated between two riparian states.

The lack of incorporation of Article 4(2)(e) is a primary reason that the Nile Basin cooperation programs and processes have stalled. Addressing the spirit of the law in Article 4(2)(e) throughout the entire CFA document may have facilitated the signing and ratification of the CFA agreement by all 10 member states. Therefore, efforts to resolve the Nile impasse should focus on addressing the core problem: how to sufficiently incorporate Article 4(2)(e) into the proposed water allocation method. This paper makes proposals on how this can be addressed in the subsequent subsections.

\subsection{Define a New Agenda (Recipient, Item, and Process)}

\subsubsection{Dimension: A Group-Based Distributive Method}

According to the study results, the eligible Nile Basin recipients are the Nile Basin States. The paper extensively describes the criteria for current eligibility of Nile Basin recipients. The criteria are summarized as follows:

1. Member-based distribution: 10 member states and one observer (Eritrea).

2. Merit-based distribution: The recipient is a member state that has met the established performance and reward system. Poor or non-performing states do not receive any water allocation.

3. Rank-based distribution: Tiered water allocation based on a Basin States' rank or level.

4. Group-based distribution: There are two established groups: the Eastern Nile and the Nile Equatorial Lakes. There is also a group-based distribution between Egypt and Sudan, which was established under the 1929 and 1959 agreements.

Equity seeks to ensure fairness in any distribution of resources. To arrive at equity, the substantive aspects of the distribution have to be just, and the process must be "justly arrived at" [62]. However, after making the distribution, who will be the recipients? According to International Water Law, the players have traditionally been the Basin States. Therefore, the traditional recipients of the Nile water allocation are the Basin States. 
However, in reality, the recipients cannot be a Nation State. The actual recipients are the Basin citizens. In every country, the governments have their resource allocation mechanisms, which vary from one riparian state to another. Therefore, it may be difficult to separate the basin citizens of one riparian state from other citizens who are not within the basin. If a country has a centralized government and all of the public resources are collected in a consolidated fund, these resources can then be distributed to the various regions (which may be completely different from the Nile Basin geographical regions in the country). Introducing another resource allocation mechanism specifically for the basin citizens within that riparian state may not be feasible. Therefore, it would be more practical to consider having the recipients as the population of people within the Basin States instead of the Basin citizens within a particular Basin State. This approach would be practical and also increase the Democratic Republic of Congo available area and resources since its basin area is only $0.9 \%$ of the entire Democratic Republic of Congo and $0.7 \%$ of the Nile Basin. However, the entire country has sizeable arable land and hydropower potential (outside the basin area) that if considered as a whole, would be a great asset to the Nile Basin.

Therefore, the paper recommends a drastic shift in thinking about who the recipients are, from the Basin States to the population within the Basin States. If the recipient is the population of the 11 states, then it is a vast population that is drastically increasing. Also, the scale covered by the 11 riparian states is massive $\left(1 / 10^{\text {th }}\right.$ of Africa). This shift in the mental model on who is the recipient is essential because it will enable scientists and policymakers to visualize the complexity of issues and facilitate the process of moving away from water allocation discourses towards development.

Once there is a mental model shift toward development, then it will be apparent that development is only possible if the scale is manageable. Therefore, group-based distribution helps reduce the scale to a more manageable level, while still maintaining the overall basin vision.

Understanding the recipient of the distribution helps policymakers to scale down to a level that is realistic. Groups can help to scale down to a manageable and realistic level and maintain the basin-wide vision.

\subsubsection{Items Dimension: A Value-Based Distribution}

The distributed item is surface water (freshwater) from the Nile River (Main Nile). Most of the literature considers allocating only the $84 \mathrm{BCM}$ annual surface Nile waters flow from the Main Nile. Few studies consider incorporating groundwater [24] and green water resources (stored rainwater in the soil as soil moisture) [13]. Most of the Nile Basin discussions define or envision the distributed item as the runoff from the Nile River (Main Nile) [42].

The research proposes a shift away from the Main Nile towards the entire Nile ecosystem. There are significant losses of water through evaporation in the Lake Victoria and Sudd sub-basins. These losses are barely taken into account. Also, as discussed earlier, there are immense benefits of constructing dams upstream, especially along the Blue Nile in Ethiopia. This critical point is ordinarily sidelined because the distributed item has for many years been the $84 \mathrm{BCM}$ in the Main Nile.

The paper proposes a significant reconsideration of the distributed item. It suggests broadening the current focus on freshwater to incorporate salty drainage basins within the Nile. The expansion may spur joint desalination projects to expand the distributed item. The paper also broadens the current focus on surface water to incorporate groundwater resources. If the item includes groundwater resources, then the pie significantly increases. Joint actions may help reduce the depletion of groundwater resources and improve water quality. The inclusion of green water expands the pie and introduces critical issues such as climate change, improving the productivity of arable lands and better managing the green water resources. Finally, the incorporation of greywater resources to ensure that the entire basin has improved water recycling projects so that the wastewater is purified and reused. All of these actions will broadly expand the pie and address the water challenges currently facing the basin.

In summary, an expansion of the distributed item should include: 
1. Both fresh and saline water resources (blue water).

2. Both surface and groundwater resources (blue water).

3. Green water resources.

4. Greywater resources that can be recycled and reused.

\subsubsection{Process Dimension: A Consensus-Based Distribution}

In the past, the adoption of the consensus approach to dispute resolution led to delays in Nile Basin processes. However, the voting and competition-based distributions have a very high probability of being rejected as unjust. Consensus-based distribution has the highest probability of attaining a just distribution, but it is almost impossible to implement. The research proposes a shift from the rational decision-making model toward a political reasoning model of decision-making, to be able to reach consensus on a water allocation method that is equitable and reasonable.

The results indicate that most of the Nile Basin decision-making processes have been using the rational decision-making model. Rational decision-making is the process of choosing an action from a set of plausible actions after an evaluation of the effects of all of the possible actions [63]. Under the rational decision-making model, the goal of policy scientists is the production and application of knowledge to inform policymaking $[64,65]$. The development of rational public policies requires three key ingredients: rational reasoning, rational society, and rational policymaking. According to Stone (2002), policymakers who use the rational model of decision-making usually undertake five critical steps [1]. First, develop objectives for the planned decision. Then, find alternate courses of action that would help them attain the planned objectives. Third, use scientific methods to predict, forecast, or anticipate the effects of each alternative cause of action. Fourth, assess the possible effects of each alternative cause of action. Finally, select the alternative that maximizes the achievement of their planned objective(s) ([1], p. 11).

The authors propose Stone's model of political reasoning in place of the rational decision-making model. The political reasoning model involves category-making and metaphor-making aimed at strategically persuading policymakers toward developing a dominant discourse and suppressing other discourses, for the sake of advancing policy ([1], pp. 11-12). The authors further propose a shift from the market model of society that assumes that society is a "collection of autonomous, rational decision-makers" ([1], p.12) toward a political model of the society. A political model of decision-making acknowledges that people are not autonomous agents. Culture, tradition, emotional bonds, and social groups connect people. Also, people's perceptions and preferences are not fixed and independent [66]. The political reasoning model captures the essence of any policymaking process: the struggle for dominance and subsequent suppression of contested views. In policymaking, ideas are not only the medium of exchange, but they are also the mode of influence. As Stone (2002) stated, "ideas are even more powerful than money, votes, and guns" ([1], p. 13). Therefore, the primary focus of policymaking should be to strive for the shared meaning that is needed to minimize conflicts and spur collective action [41].

\subsection{Replicability of the Research Approach in Similar River Basins}

The Stone (2002) concept on equality was chosen for this study because it is a simple definition of equality that every policymaker can easily visualize as a starting point before getting into the various water allocation methods. It is a valuable framework because it starts with a simple model that increases in complexity as the research progresses. It is a framework that can be used by scientists and policymakers in many circumstances to support water allocation decisions.

This research recommends the use of the Stone (2002) framework together with the nine CFA factors at a smaller scale in the basin. Follow-up studies would help advance some of the recommendations made in this paper or verify the viability of the proposed distribution methods. The research method applies to any of the Nile sub-basins, namely: Main Nile, Atbara, Blue Nile, White Nile, Baro-Pibor-Sobat, Bahr el Gazal, Sudd (Bahr el Jebel), Victoria-Albert Nile, and Lake 
Victoria [24]. Beyond the Nile Basin, the current study can be replicated in basins within Africa that face similar challenges. Some of the possible basins to apply the approach include Volta, Zambezi, Senegal, Congo, Limpopo, Okavango, Senegal and Orange River Basins. The CFA provisions do not apply to other river basins in Africa. Therefore, the nine CFA factors should be replaced by the United Nations Water Courses Convention (UNWC) list of seven factors that are relevant to equitable and reasonable utilization [32].

Overall, the approach adopted in this study is replicable within the Nile Basin at the basin-wide level, as well as at the sub-basin level and also smaller scales (local, national). At the African level, the approach can be replicated in all of the large complex basins facing similar water scarcity challenges. However, to adopt the approach outside the Nile Basin, there is a need to use either an existing agreement between the Basin States of a particular river basin or the provisions of Article 6(1) of the United Nations Water Courses Convention (1997).

\section{Conclusions}

The criteria that was developed in this paper for assessing a fair water allocation method sought to operationalize the equitable and reasonable utilization principle, which is a core water allocation principle in the International Water Law. One key outcome of the analysis was the lack of a shared meaning on how to address the Nile Basin equitable allocation challenge. It was also evident that many sets of discourses exist on how to address the Nile Basin equity challenge. Some of these discourses seem to be slowly developing into dominant discourses. Unfortunately, the process is haphazard and slow. Policy analysts may support the process of reframing and develop a shared meaning, and if need be, suppress alternative discourses that may not lead to a fair outcome.

In this research, we implement the van Eeten (1999) four-step process for defining new agendas:

Step 1 Reconstruct the policy arguments to the debate.

Step 2 Compare and contrast arguments to understand the debate character better.

Step 3 Identify a crosswalk position.

Step 4 Define a new agenda to recast the issue.

In Step 1, we adopted Stone's (2002) basic definition of equality by evenly distributing the total sum of Nile water discharge between the 11 riparian states: each country gets less than $30 \mathrm{~mm}$ in depth. Although this distribution ensures an equal allocation of the water resources amongst the 11 riparian states, the approach is unfair based on nine distributive challenges of equality. We discussed these distributive challenges in more detail in Section 3. Then, we compared and contrasted the current Nile Basin discourses to understand the water allocation debate better (Step 2). Afterward, we identified a recipient item process-based water allocation method as a crosswalk position (Step 3). Finally, we defined a new agenda for the Nile Basin (Step 4).

The interpretative policy analysis results indicated that none of the nine definitions of equity derived from Stone's (2002) equality conceptual framework met the Nile Basin CFA criteria for determining equitable and reasonable utilization. For operational purposes, the paper proposes a combined method that addresses eight of the nine factors that are relevant in determining equitable and reasonable utilization. An outline of the proposed water allocation method is as follows:

1. Recipients Dimension: A group-based distributive method.

2. Items Dimension: A value-based distribution. Need-based distribution does not help to resolve the scarcity issue. However, a value-based distribution that ensures that the benefits are used to address the needs is preferable.

3. Process Dimension: A consensus-based distribution (process dimension). Since there is a link between recipients and items dimensions, if the recipients are correctly identified, and the item focus is selected, then the dangers of process bias are reduced.

An important factor that is not accounted for in all of the proposed water allocation methods is Article 4(2)(e) of the CFA. The provisions of Article 4(2)(e) (incorporate existing and potential uses) 
nullify the purpose of any water allocation method. The current water use leaves no room for further water allocation.

Therefore, the paper proposes to:

1. Broaden the recipient focus to ensure that all of the interventions focus on the population living in the 11 Nile Basin states. The expansion will widen the scope of the problem and provide better lenses for the solution.

2. Broaden the scope of the item being distributed to include:
a. Both fresh and saline water resources (blue water)
b. Both surface and groundwater resources (blue water)
c. Green water resources
d. Greywater resources that can be recycled and reused.

3. Broaden the decision-making process to strive for consensus-based distribution. Since consensusbased distribution is a complicated process, there needs to be a shift in the policy-making process from the current rational decision-making model toward political reasoning. The paper proposes a shift from:

a. The voting model of decision-making towards consensus-based

b. The rational model decision making to political reasoning model of decision-making.

The strength of the method is that the criteria are transparent and straightforward, making it easy for decision-makers and politicians to understand, appreciate, and apply it. Since the determination of equitable and reasonable utilization is a joint effort that requires the participation of multiple actors from the respective Basin States, a simple, transparent criterion is vital for building trust and increasing situation awareness and thus enhancing cooperation. The proposed water allocation method aims to stimulate critical thinking about the equitable and reasonable utilization of the Nile Basin water resources. It may facilitate reaching a consensus through the expansion of available options. Researchers and policy analysts can apply the method in Nile Basin sub-basins and similar basins within Sub-Saharan Africa.

Author Contributions: A.M.O., the first and corresponding author conceptualized the article, designed the methodology, undertook the interpretative policy analysis and the investigation of the Nile Basin water allocation issue in the context of equitable and reasonable utilization. The first and corresponding author also wrote the original draft and was actively involved in the draft preparation, content visualization, draft improvement and the incorporation of comments from the second author and the reviewers. B.V.d.W., the second author, improved the initial conceptualization, methodology and was actively involved in the validation process. The second author was also responsible for resources, review \& editing, supervision, project administration and formal analysis.

Conflicts of Interest: The authors declare no conflict of interest.

\section{References}

1. Stone, D. Policy Paradox; WW Norton \& Company: New York, NY, USA, 2002.

2. Wolf, A.T. International water conflict resolution: Lessons from comparative analysis. Int. J. Water Resour. Dev. 1997, 13, 333-366. [CrossRef]

3. McCaffrey, S.C. The Law of International Watercourses; Oxford University Press on Demand: Oxford, UK, 2007.

4. Wouters, P. International Law_Facilitating Transboundary Water Cooperation; Global Water Partnership: Stockholm, Sweden, 2013.

5. McIntyre, O. Environmental Protection of International Watercourses under International Law; Routledge: Abingdon, UK, 2016.

6. Wolf, A.T. Criteria for equitable allocations: The heart of international water conflict. In Natural Resources Forum; Wiley Online Library: Hoboken, NJ, USA, 1999.

7. Rahaman, M.M. Principles of international water law: Creating effective transboundary water resources management. Int. J. Sustain. Soc. 2009, 1, 207-223. [CrossRef] 
8. The Helsinki Rules. The Helsinki Rules on the Uses of the Waters of International Rivers; International Law Association: London, UK, 1966.

9. International Law Association. Berlin rules on water resources. In Proceedings of the Seventy-First Conference, Berlin, Germany, 16-21 August 2004; International Law Association: London, UK, 2004.

10. Secretariat of the United Nations Commission for Europe. Protection and use of transboundary watercourses and international lakes in Europe. In Natural Resources Forum; Wiley Online Library: Hoboken, NJ, USA, 1994.

11. Mekong River Commission. Agreement on the Cooperation for the Sustainable Development of the Mekong River Basin; Mekong River Commission Secretariat: Phnom Penh, Cambodia, 1995.

12. Southern African Development Community (SADC). Protocol on Shared Watercourse Systems; Southern African Development Community: Gaborone, Botswana, 1995.

13. Van der Zaag, P.; Seyam, I.M.; Savenije, H.H. Towards measurable criteria for the equitable sharing of international water resources. Water Policy 2002, 4, 19-32. [CrossRef]

14. Postel, S. The Last Oasis: Facing Water Scarcity; Routledge: London, UK, 2014.

15. Lankford, B. Does Article 6 (Factors Relevant to Equitable and Reasonable Utilization) in the UN Watercourses Convention misdirect riparian countries? Water Int. 2013, 38, 130-145. [CrossRef]

16. Dellapenna, J.W. The Berlin rules on water resources: The new paradigm for international water law. In Proceedings of the World Environmental and Water Resource Congress 2006: Examining the Confluence of Environmental and Water Concerns, Omaha, Nebraska, 21-25 May 2006.

17. Van Eeten, M.J.G. Dialogues of the Deaf: Defining New Agendas for Environmental Deadlocks; Eburon Publishers: Delft, The Netherlands, 1999.

18. Sabatier, P.A. An Advocacy Coalition Framework for Policy Change and the Role of Policy-Oriented Learning Therein. Policy Sci. 1988, 21, 129-168. [CrossRef]

19. Jenkins-Smith, H.C.; Sabatier, P.A. The dynamics of policy-oriented learning. In Policy Change and Learning: An Advocacy Coalition Approach; Westview Press: Boulder, CO, USA, 1993; pp. 41-56.

20. Kleiboer, M.; Hart, P. Time to talk? Multiple perspectives on timing of international mediation. Coop. Confl. 1995, 30, 307-348. [CrossRef]

21. Roe, E. Narrative Policy Analysis: Theory and Practice; Duke University Press: Durham, UK, 1994.

22. Hoppe, R.; Hisschemöller, M. Coping with Intractable Controversies: The Case for Problem Structuring in Policy Design and Analysis. In Knowledge, Power, and Participation in Environmental Policy Analysis; Springer: Dordrecht, The Netherlands, 2018; pp. 47-72. [CrossRef]

23. Fischer, F. Evaluating Public Policy; Nelson-Hall: Chicago, IL, USA, 1995.

24. Nile Basin Initiative (NBI). State of the River Nile Basin Report; Nile Basin Initiative: Entebbe, Uganda, 2012.

25. Environmental Remote Sensing Laboratory. Effects of the Indian Ocean Temperature on Nile River Flow Volumes; University of Toledo: Toledo, OH, USA, 2018.

26. Salazar, J.F.; Villegas, J.C.; Rendón, A.M.; Rodríguez, E.; Hoyos, I.; Mercado-Bettín, D.; Poveda, G. Scaling properties reveal regulation of river flows in the Amazon through a forest reservoir. Hydrol. Earth Syst. Sci. 2018, 22, 1735. [CrossRef]

27. Nile Basin Initiative (NBI). Chapter 3: The Socio-Economic Profiles of the Countries. In The Nile Basin Water Resources Atlas; Akol, P.J., Galla, R.P.Z., Wanyony, S., Eds.; Nile Basin Initiative (NBI): Entebbe, Uganda, 2016.

28. Whittington, D.; Wu, X.; Sadoff, C. Water resources management in the Nile basin: The economic value of cooperation. Water Policy 2005, 7, 227-252. [CrossRef]

29. Onencan, A.M.; Enserink, B.; Kortmann, L.J.; Thissen, W.A. Weshareit: A Nexus Approach to Nile Basin Water Resources Management. In Decision Making under Deep Uncertainty; Delft University of Technology: Delft, The Netherlands, 2015.

30. Onencan, A.; Enserink, B.; Van de Walle, B.; Chelang'a, J. Coupling Nile Basin 2050 Scenarios with the IPCC 2100 Projections for Climate-induced Risk Reduction. In Proceedings of the Humanitarian Technology: Science, Systems and Global Impact 2016 (HumTech2 016), Boston, MA, USA, 7-9 June 2016.

31. Nile Basin Initiative. Agreement on the Nile River Basin Cooperative Framework; Nile Basin Initiative: Entebbe, Uganda, 2009; Volume 42.

32. United Nations. Convention on the Law of the Non-Navigational Uses of International Watercourses; United Nations: Geneva, Switzerland, 1997; p. 18.

33. Godana, B.A. Africa's Shared Water Resources: Legal and Institutional Aspects of the Nile, Niger, and Senegal River Systems; F. Pinter: London, UK; Boulder, CO, USA, 1985; p. 370. 
34. Hamada, Y.M. Effects of Dams and Barrages on River Channels. In The Grand Ethiopian Renaissance Dam, Its Impact on Egyptian Agriculture and the Potential for Alleviating Water Scarcity; Springer: Cham, Switzerland, 2017; pp. 59-75.

35. Cascão, A.E. Changing power relations in the Nile river basin: Unilateralism vs. cooperation? Water Altern. 2009, 2, 245.

36. Myers, N. Environmental Security: What's New and Different? In Proceedings of the Hague Conference on Environment, Security and Sustainable Development, The Hague, The Netherlands, 9-12 May 2004.

37. Starr, J.R. Water wars. Foreign Policy 1991, 82, 17-36. [CrossRef]

38. Váli, F.A. Servitudes of International Law: A Study of Rights in Foreign Territory; Fred B. Rothman: Littleton, CO, USA, 1958.

39. Garretson, A.H. The Nile river system. In Proceedings of the American Society of International Law at Its Annual Meeting (1921-1969); Cambridge University Press: Cambridge, UK, 1960.

40. Kamau, J. Can East Africa win the Nile War? Daily Nation 2002, 5.

41. Onencan, A.; Van de Walle, B.; Enserink, B.; Chelang'a, J.; Kulei, F. WeShareIt Game: Strategic Foresight for Climate-change Induced Disaster Risk Reduction. In Proceedings of the Humanitarian Technology: Science, Systems and Global Impact 2016 (HumTech 2016), Boston, MA, USA, 7-9 June 2016.

42. Swain, A. The Nile River Basin Initiative: Too many cooks, too little broth. SAIS Rev. 2002, 22, $293-308$. [CrossRef]

43. Guariso, G.; Whittington, D. Implications of Ethiopian water development for Egypt and Sudan. Int. J. Water Resour. Dev. 1987, 3, 105-114. [CrossRef]

44. Nicol, A.; Shahin, M. The Nile: Moving Beyond Cooperation; UNESCO: Paris, France, 2003.

45. Salman, S.M. Downstream riparians can also harm upstream riparians: The concept of foreclosure of future uses. Water Int. 2010, 35, 350-364. [CrossRef]

46. United Nations Development Programme (UNDP). Human Development Report 2016: Human Development for Everyone; Incorporated, C.D., Ed.; United Nations Development Programme: Washington, DC, USA, 2016; p. 286.

47. Enserink, B.; Onencan, A. Nile Basin Scenario Construction. In Proceedings of the 37th Annual Conference of the International Association for Impact Assessment, Montreal, QC, Canada, 4-7 April 2017.

48. Onencan, A.M.; Enserink, B. The Nile Basin by 2050: Strategic Foresight on the Nile Basin Water Governance; Nile Basin Discourse: Entebbe, Uganda, 2014; Volume 28.

49. Onencan, A.M.; Enserink, B.; van de Walle, B. Game Design Concept Report: Application of the We Share It Game Elements in Nzoia River Basin; Delft University of Technology: Delft, The Netherlands, 2018; p. 53.

50. United Nations Environment Programm (UNEP). Adaptation to Climate Change Induced Water Stress in the Nile Basin: A Vulnerability Assessment Report; Kironde-Gowa, E., Ed.; UNEP: Nairobi, Kenya, 2013.

51. African Development Bank (AfDB). Policy on Integrated Water Resources Management; Africa Development Bank: Abidjan, Côte d'Ivoire, 2000; p. 93.

52. Whittington, D.; Waterbury, J.; Jeuland, M. The Grand Renaissance Dam and prospects for cooperation on the Eastern Nile. Water Policy 2014, 16, 595-608.

53. Siam, M.S.; Eltahir, E.A. Climate change enhances interannual variability of the Nile river flow. Nat. Clim. Chang. 2017, 7, 350-354. [CrossRef]

54. Walsh, R.; Davies, H.; Musa, S. Flood frequency and impacts at Khartoum since the early nineteenth century. Geogr. J. 1994, 160, 266-279. [CrossRef]

55. Betrie, G.D.; Mohamed, Y.A.; van Griensven, A.; Srinivasan, R. Sediment management modeling in the Blue Nile Basin using SWAT model. Hydrol. Earth Syst. Sci. 2011, 15, 807-818. [CrossRef]

56. Salman, S.M. The Declaration of Principles on the Grand Ethiopian Renaissance Dam: An Analytical Overview. In Ethiopian Yearbook of International Law 2016; Springer: Cham, Switzerland, 2017; pp. $203-221$.

57. Shema, N. The Failings and Future of Nile Basin Management; University of Oregon, Eugene Google Scholar: Eugene, OR, USA, 2009.

58. Gouda, D.M. The Grand Ethiopian Renaissance Dam, Agriculture, and the Rural Poor in Egypt; Springer: Berlin/Heidelberg, Germany, 2017.

59. Sutcliffe, J.V.; Parks, Y.P. The Hydrology of the Nile; International Association of Hydrological Sciences: Oxfordshire, UK, 1999. 
60. Bressen, T. Consensus decision making. In The Change Handbook: The Definitive Resource on Today's Best Methods for Engaging Whole Systems; Berrett-Koehler: San Francisco, CA, USA, 2007; pp. 212-217.

61. Steelman, T.A.; Ascher, W. Public involvement methods in natural resource policy making: Advantages, disadvantages, and trade-offs. Policy Sci. 1997, 30, 71-90. [CrossRef]

62. Harvey, D. Social Justice, and the City; Edward Arnold: London, UK, 1973.

63. Barraclough, D.J.; Conroy, M.L.; Lee, D. Prefrontal cortex, and decision making in a mixed-strategy game. Nat. Neurosci. 2004, 7, 404-410. [CrossRef] [PubMed]

64. Lasswell, H.D. A Pre-View of Policy Sciences; Elsevier Publishing Company: New York, NY, USA, 1971.

65. Dunn, W.N. Public Policy Analysis; Routledge: Prentice Hall, NY, USA, 2015.

66. Gomes, S.L.; Hermans, L.M. Institutional function and urbanization in Bangladesh: How peri-urban communities respond to changing environments. Land Use Policy 2017. [CrossRef]

(C) 2018 by the authors. Licensee MDPI, Basel, Switzerland. This article is an open access article distributed under the terms and conditions of the Creative Commons Attribution (CC BY) license (http://creativecommons.org/licenses/by/4.0/). 